\title{
JURY NULLIFICATION: THE CONTOURS OF A CONTROVERSY*
}

\author{
Alan Scheflin $\dagger$ \\ AND \\ JON VAN DYKE $\ddagger$
}

Contents

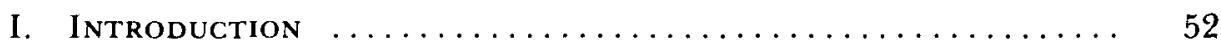

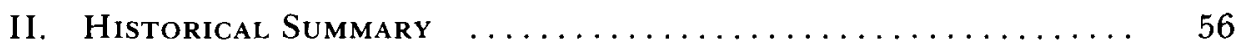

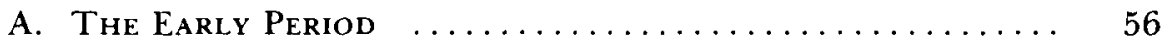

B. The Nineteenth Century Revision $\ldots \ldots \ldots \ldots \ldots \ldots \ldots . \ldots 9$

III. Recent Judicial Attitudes Toward Jury Nullification $\ldots . .63$

IV. The Lawmaking Powers of Juries in Other Contexts $\ldots . .68$

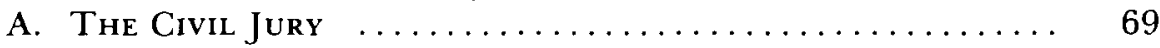

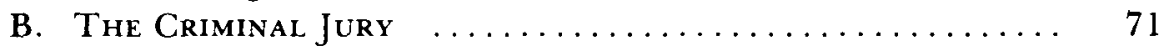

C. The U.S. Supreme Court's Recent Views on the Jury's

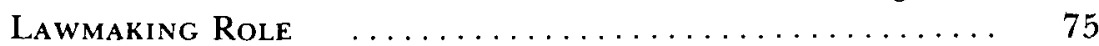

V. How Jury Nullification Works in Practice Today ....... 79

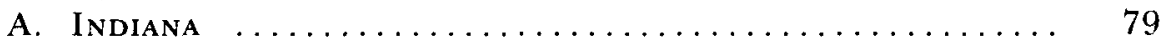

1. Can the Jury Declare a Statute to be Unconstitu-

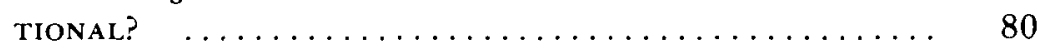

2. Can the Jury Define or Create Crimes? . . . . . . 80

3. Can the Jury Return a Conviction for a Lesser Offense When the Evidence Does Not Support a Conviction for This Offense? ............. 81

4. Can the Court Give Mandatory Instructions? .... 82

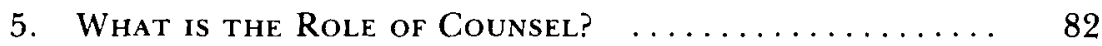

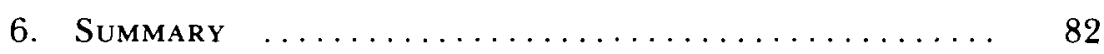

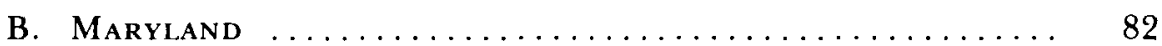

1. The Nature of the Instruction $\ldots \ldots \ldots \ldots \ldots \ldots \ldots . \ldots 3$

2. How Maryland's Trial Judges View the Instruc-

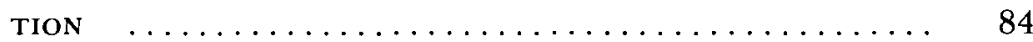

* Copyright ${ }^{\circ} 1980$ by Alan Scheflin and Jon Van Dyke. The authors would like to thank University of Hawaii law students James Williston and Raymond G. Duvauchelle for their assistance in helping to prepare this article for publication.

$\dagger$ Member of the District of Columbia bar. Professor of Law, University of Santa Clara.

$\ddagger$ Member of the District of Columbia, California, and Hawaii bars. Professor of Law, University of Hawaii. 
VI. The Current Debate Over Jury Nullification $\ldots \ldots \ldots \ldots .85$

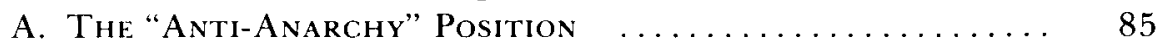

B. The "Nullification-Is-Unnecessary" Position $\ldots \ldots \ldots .90$

C. The "Nullification-Is-Unwise" Position $\ldots \ldots \ldots \ldots \ldots .91$

D. The "Damn-Good-Reason" Position f............ 98

1. Will the AcQuittal Rate Increase if the Nullifi-

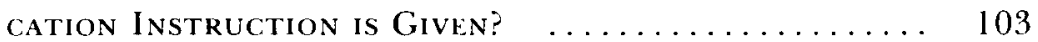

2. Honesty Is the Best Policy ................ 105

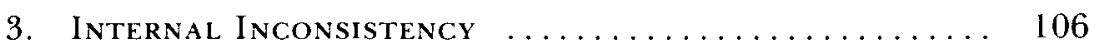

4. The Nullification Instruction Would Produce

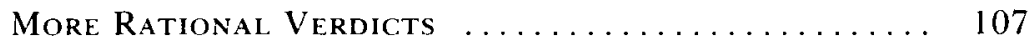

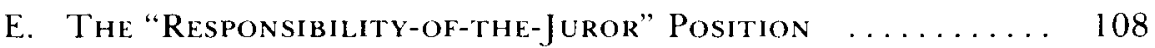

VII, Conclusion and Summary $\ldots \ldots \ldots \ldots \ldots \ldots \ldots \ldots \ldots \ldots \ldots \ldots \ldots$

\section{INTRODUCTION}

Must a jury always apply the judge's instructions on the law rigorously to the facts of a criminal case and convict whenever the law has been violated: Or should the jurors also be told that they should consider whether it would be fair and just to apply the full force of the criminal law to an accused person, and that they should refuse to convict if a guilty verdict would be inconsistent with community standards of justice and fair play?

Consider the 1973 trial of twenty-eight religiously-motivated antiwar activists in the federal court in Camden, New Jersey. ${ }^{1}$ These individuals were caught red-handed by the Federal Bureau of Investigation (FBI) immediately after they destroyed records of their local selective service office. Evidence later revealed that the FBI had been told of the activists' plans at an early stage, and that the FBI's informant had supplied the activists with the tools and knowledge to carry out their act of civil disobedience.

At the trial, Judge Clarkson S. Fisher permitted the defendants to make statements about their purposes and political feelings, and allowed the jury to hear testimony about the Pentagon Papers and the nature of the Vietnam War. But even more significantly, Judge Fisher allowed defense attorney David Kairys to make an impassioned closing argument to the jury about their right to acquit in these circumstances. ${ }^{2}$ The judge had told the jury previously

1. United States v. Anderson, Crim. No. 602-71 (D.N.J. 1973).

2. David Kairy's closing argument included the following statements:

Now. l'd like to move on-and I am almost done now-to the second reason why I think this case is not simple and why I think these defendants should be acquitted. And that's jury nullification.

Now, the term 'nullification' I think is a bad term. It's used to describe the power of a jury to acquit if they believe that a particular law is oppressive. or if they believe that a law is fair, but to apply it in certain circumstances would be oppressive. 
that they did not have the power to nullify, but, after argument by counsel, he changed his mind. Judge Fisher told the jury that his earlier comment had been incorrect. He specifically instructed them:

if you find that the overreaching participation by Government agents or informers in the activities as you have heard them was so fundamentally unfair to be offensive to the basic standards of decency, and shocking to the universal sense of justice, then you may acquit any defendant to whom this defense applies. [emphasis added $]^{3}$

The jury acquitted all twenty-eight defendants.

For contrast, consider the 1969-70 Chicago Conspiracy Trial where eight men were accused of plotting to cause violence at the 1968 Democratic Convention. At the beginning of this trial, Federal District Judge Julius J. Hoffman told the jurors that they must always follow his instructions on matters of law. Defense lawyer Leonard Weinglass immediately objected:

The defense will contend that the jury is a representative of the moral conscience of the community. If there is a conflict between the judge's instructions and that of conscience, it should obey the latter. ${ }^{4}$

Judge Hoffman overruled the objection and the jury subsequently convicted five of the defendants. ${ }^{5}$

Which approach is preferable? Judge Hoffman's ruling is certainly the more typical judicial attitude. In recent years, most American judges have in-

\footnotetext{
Now, the second situation might be something like the Boston Tea Party. No one would say that breaking into a ship shouldn't be criminal, shouldn't be a crime. But in those particular circumstances, should people be convicted of doing that? That's the question.

This power that jurors have is the reason why we have you jurors sitting there instead of computers. Because you are supposed to be the conscience of the community. You are supposed to decide if the law, as the Judge explains it to you, should be applied or if it should not. Nothing the Judge would say to you is inconsistent with this power.

It's not a request on our part that you show any disrespect for the law. It's part of the law .... It's as essential as reasonable doubt. It's the same kind of function.

You decide, considering the circumstances of the case, should you brand the defendants as criminal. And it's very important in that regard, that you are only required to say guilty or not guilty. That's what people call the general verdict. You don't have to give reasons. You don't have to give specifics. You don't have to justify what you did; and if you say not guilty, it can't be reviewed by any Court.

... Are they deserving of the community's scorn-you being the community-or are they not deserving of the community's scorn? That's what the question is. [emphasis added]
}

Transcript at 8386-94, United States v. Anderson, Crim. No. 602-71 (D.N.J. 1973). For a more complete version of Kairys's closing statement, see J. Van Dyke, Jury Selection Procedures: Our Uncertain Commitment ro Representative Panels 239-40 (1977) [hereinafter cited as J. VAN Dyke, Jury SElection].

3. Transcript at 8729, United States v. Anderson, Crim. No. 602-71 (D.N.J. 1973), reprinted in J. VAN Dyke, Jury Selection, supra note 2, at 238-39.

4. N.Y. Times, Sept. 26, 1969, at 25 (city ed.).

5. Judge Hoffman's ruling on this issue was upheld in United States v. Dellinger, 472 F.2d 340, 408 (7th Cir. 1972), cert. denied, 410 U.S. 970 (1973); the convictions were, however, reversed on other grounds. 
sisted that they alone can articulate and interpret the law and that the role of the jury is simply to evaluate the evidence, decide what happened, and then apply the law-as enunciated by the judge-to the facts. ${ }^{6}$ Indeed, this jury instruction is so commonplace that any other advice to the jury is scarcely imaginable in most courts.

But for much of the seventeenth, eighteenth, and nineteenth centuries, jurors were told frequently that they had the right and power to reject the judge's view of the law. ${ }^{7}$ In recent years, many defense lawyers and scholars have tried to keep a portion of this tradition alive by arguing for what they believe to be a more candid, just, and democratic view of the role of the jury. ${ }^{8}$ The doctrine of "jury nullification" includes the defendant's right to have the jurors instructed that they have the power to refuse to apply a law (or "nullify" its effect) in situations when the strict application of the law would lead to an unjust or inequitable result. The appropriate jury nullification instruction has been described as follows:

Jurors should ... be told that although they are a public body bound to give respectful attention to the laws, they have the final authority to decide whether or not to apply a given law to the acts of the defendant on trial

6. See, e.g., Morris v. United States, 156 F.2d 525, 531 (9th Cir. 1946); Berra v. United States, 351 U.S. 131, 134 (1956); United States v. Marchese, 438 F.2d 452, 455 (2d Cir. 1971); United States v. Simpson, 460 F.2d 515, 519 (9th Cir. 1972); United States v. Dougherty, 473 F.2d 1113, 1130-37 (D.C. Cir. 1972); State v. McClanahan, 212 Kan. 208, 510 P.2d 153, 158 (1973); United States v. Moylan, 417 F.2d 1002, 1006 (4th Cir. 1969), cert. denied, 397 U.S. 910 (1970); Arshack v. United States, 321 A.2d 845,850 (D.C. Ct. App. 1974).

7. There was only one judge in the United States who, between 1776 and 1800 , was to deny the jury the right to decide law in criminal cases ... . He was afterwards impeached by the House of Representatives of Pennsylvania and removed by the Pennsylvania Senate, on the grounds of interference with the rights [of] a fellow judge in the charging of grand and petit juries.

Lloyd E. Moore, The Jury: ToOl of Kings, Palladium of Liberty, at 107 (1973).

Until nearly forty years after the adoption of the Constitution of the United States, not a single decision of the highest court of any State, or of any judge of a court of the United States, has been found, denying the right of the jury upon the general issue in a criminal case to decide, according to their own judgment and consciences, the law involved in that issue-except the two or three cases . . concerning the constitutionality of a statute. And it cannot have escaped attention that many of the utterances . . . maintaining the right of the jury, were by some of the most eminent and steadfast supporters of the Constitution of the United States, and of the authority of the national judiciary.

Sparf and Hansen v. United States, 156 U.S. 51, 168 (Gray, J., dissenting.)

8. See, e.g., Howe, Juries As Judges of Criminal Law, 52 Harv. L. Rev. 582 (1939); Sax, Conscience and Anarchy: The Prosecution of War Resisters, 57 YALE REviEw 481 (1968); Kunstler, Jury Nullification in Conscience Cases, 10 VA. J. Int'L L. 71 (1969); Van Dyke, The Jury As A Political Institution, 16 Сатн. LAw. 224 (1970) and 3 The Center Magazine 17 (No. 2, March-April 1970); Scheflin, Jury Nullification: The Right To Say No, 45 So. CaL. L. Rev. 168 (1972); Sperlich, Trial by Jury: It May Have a Future, 1978 The Supreme Court Review 191, 193 note 10. Jury nullification has been argued by defense lawyers in almost every major political case in the last fifteen years. We will discuss some of these cases and arguments later in this article. An excellent book which discusses the jury from the perspective of defense advocacy is A.F. Ginger, JURy SELECTION IN Criminal Trials: New Techniques and Concepts (1975) (Chapter 15 discusses jury nullification). 
before them. More explicitly, jurors should be told that they represent their communities and that it is appropriate to bring into their deliberations the feelings of the community and their own feelings based on conscience. Finally, they should be told that despite their respect for the law, nothing would bar them from acquitting the defendant if they feel that the law, as applied to the fact situation before them, would produce an inequitable or unjust result. ${ }^{9}$

This instruction allows juries to be merciful toward a defendant in those unusual and rare situations when a strict application of a specific law would lead to a result that is inconsistent with community notions of justice and fairness. It does not permit jurors to "make law" or to convict an accused of some act not covered by a statute and the indictment. Judges would reverse such a conviction if it occurred, as they do now.

Even without such an instruction, in a small but significant number of cases, juries return verdicts of "not guilty" despite strong evidence to the contrary because they feel the application of the law to the defendant would lead to an unjust result. ${ }^{10}$ This "dispensing power"11 is acknowledged by all observers of the jury system, even those who disapprove of the nullification instruction. ${ }^{12}$

The critical issue in recent years has become whether the defendant has the right to have the jury instructed as to its universally-recognized power. In Arschack v. United States, ${ }^{13}$ the District of Columbia Court of Appeals said that to instruct the jury of its power to nullify "would actually encourage anarchy in the courtroom" that "might in the end harmfully infect organized society." 14 We will attempt to demonstrate that this view misrepresents the nature of the nullification instruction and misstates the likely consequences of giving it. We will argue that giving the nullification instruction allows the jury to operate in a more honest and just fashion. In our opinion, the failure to tell the jury of its power to nullify seriously weakens the concept of "jury," thereby impermissibly diluting the defendant's Sixth Amendment rights.

Historically, three jury-power arguments have been made and the failure to carefully distinguish between them continues to cause unnecessary confusion in the modern literature on jury nullification.

The first power a jury might exercise is the power to interpret and ultimately decide all questions of law. In many early courts, the judge's interpretation of the law was not binding on the jury and could be challenged by the attorneys

9. Van Dyke, supra note 8 , at 241 .

10. See H. Kalven \& H. Zeisel, The American Jury passim (1966) [hereinafter cited as H. Kalven \& H. ZeiSEL].

11. Brown v. United States, 334 F.2d 488, 500 (9th Cir. 1964).

12. See, e.g., State v. McClanahan, 212 Kan. 208, 214, 510 P.2d 153, 158 (1973); United States v. Dougherty, 473 F.2d 1113, 1130 (D.C. Cir. 1972).

13. 321 A.2d 845 (1974)

14. Id. at 851 . 
in the case. ${ }^{15}$ The judge would give instructions on the law, followed by the government's and defense attorney's interpretations of the law. The jury would then retire to decide which interpretation, if any, it favored. Most modern proponents of a jury nullification instruction do not believe that the jury has or should have this type of power. Proponents of jury nullification accept the right of the judge to instruct the jury on the law, and they support the instruction that this interpretation is binding.

The second power a jury might exercise is that of declaring a statute unconstitutional. Jury nullification "has occasionally been argued to include the right of the jury to declare a statute unconstitutional." ${ }^{6}$ Although this issue was hotly debated in the nineteenth century, today virtually everyone agrees that it is absurd to think that juries can invalidate statutes. A jury's refusal to convict a defendant might be based on a belief that a statute is unconstitutional, but a jury's decision cannot have direct effect beyond the case at hand; a jury cannot eliminate a statute from the law books. Thus, jury nullification does not include the authority to declare statutes unconstitutional.

The third power a jury might have is to acquit the defendant on the basis of conscience even when the defendant is technically guilty in light of the judge's instructions defining the law and the jury's finding of the facts. This power constitutes jury nullification. Of the three powers discussed, this one is clearly the least revolutionary and the most defensible. This power is the focus of our article. In our judgment, jurors should be instructed that they have this important power of nullification.

\section{I}

\section{Historical SUMmary}

\section{A. The Early Period}

Juries began asserting their nullification power at the same time that they were asserting their independence in other respects. The history of jury nullification is a rich one. Although it has been reviewed in detail elsewhere, ${ }^{17}$ selected highlights will be examined in this Section because the history is essential to understanding the modern debate.

The first clear acceptance of the jury as an independent decision-making body came in the 1670 London trial of William Penn and William Mead. ${ }^{18}$

15. For a modern version of this argument, see J. Stein, Closing Argument: The Art and THE LAW 49-53 (1969).

16. Scheflin, supra note 8 , at 169 n.2.

17. See, e.g., Howe, supra note 8, at 583-96; Scheflin, supra note 8, at 169-81; Van Dyke, supra note 8, at 225-29: Note, Jury Nullification in Historical Perspective: Massachusetts as a Case Study. 12 SUFF(l.K U. L. REv. 968, 976-1003 (1978).

18. Penn \& Mead's Case, 6 Howfll.'s Statr. Trials 95l (London 1816) (1st ed. London 
The jury refused to follow the judge's instructions on the law ordering them to convict. For this act of disobedience, several jurors were forced to spend months in jail insisting on their right to make the final decision on the guilt or innocence of the accused. The subsequent vindication of their position is commemorated in the Old Bailey courthouse in London-the only trial to be so remembered. ${ }^{19}$

The broader right of the jury to pass on questions of law as well as issues of fact was quickly accepted in England, and spread to the North American colonies where juries periodically refused to convict for violations of the Crown's laws. Colonial juries regularly refused, for instance, to enforce the navigation acts designed by the British Parliament to channel all colonial trade through England. Ships impounded by the British for violations of trade restrictions were released by juries in disregard of law. ${ }^{20}$

The most famous colonial example of jury nullification was the case of John Peter Zenger, the only printer in New York who would publish material without the authorization of the British mayor. Under British law, printing such material was criminal sedition and truth was no defense to the charge. Zenger's lawyer, Andrew Hamilton, told the jurors that they "ha[d] the right beyond all dispute to determine both the law and the fact[s]." ${ }_{11}$ The jury followed his advice, acquitted Zenger, and again demonstrated the jury's role as the ultimate arbiter of criminal disputes.

By the end of the eighteenth century, this principle was accepted by the leaders who helped form the colonies into a nation. John Adams, one of the more conservative leaders of this period, wrote in his diary in 1771:

1783). The jury was vindicated in Bushell's Case, id. at 999. See J. Van Dyke, Jury Selection, supra note 2, at 5 .

19. The memorial hung in the courthouse reads as follows:

Near this site William Penn and William Mead were tried in 1670 for preaching to an unlawful assembly in Gracechurch Street.

This tablet commemorates the courage and endurance of the Jury, Thomas Vere, Fdward Bushell and ten others, who refused to give a verdict against them although they were locked up without food for two nights and were fined for their final verdict of Not Guilty.

The case of these jurymen was reviewed on a writ of Habeas Corpus and Chief Justice Vaughan delivered the opinion of the court which establishes the Right of the Juries to give their Verdict according to their conviction. [emplasis added]

20. Because North American juries refused to follow the law in these cases, the British established courts of vice-admiralty to try maritime cases (including violations of the navigation acts) without a jury, a source of great bitterness among the colonists and one of the many grievances that culminated in the revolution. See 4 C. Andrews, The Colonial Period of American HisTORY 140ff., 152ff., 222-27, $25 \mathrm{lff}$ (1934). One of the grievances listed in the Declaration of Independence is the denial of the right of trial by jury in certain cases, an apparent reference to, among other things, the courts of vice-admiralty. See id. at 270 , and see generally, L. Moore, supra note 7. at $107-13$

21. A Briff Narkation of the Case and Trial of John Peter Zenger 78 (J. Alexander ed. 1963). 
Now, should the melancholy case arise that the judges should give their opinions to the jury against one of these fundamental principles, is a juror obliged to find his verdict generally, according to this direction, or even to find the fact specially and submit the law to the court? Every man of any feeling or conscience, will answer no. It is not only his right, but his duty, in that case to find the verdict according to his own best understanding, judgment, and conscience, though in direct opposition to the directions of the court. [emphasis added] ${ }^{22}$

A 1794 civil case, heard before the U.S. Supreme Court under its original jurisdiction, is another example of the widespread acceptance of this jury power. Chief Justice John Jay, after instructing the jury on the law and advising them that, as a general rule, they should take the law from the court, told the jurors:

But it must be observed that by the same law, which recognizes this reasonable distribution of jurisdiction, you have, nevertheless, a right to take upon yourselves to judge of both, and to determine the law as well as the fact in controversy. [emphasis added ${ }^{23}$

Justices James Iredell and James Wilson were on the Supreme Court in 1794 and expressed agreement in another case with the doctrine that the jurors can judge the law. ${ }^{24}$ Even the politically repressive Sedition Law of 1798 adhered to this principle of jury authority by providing that in prosecutions for seditious libel, "the jury who shall try the cause shall have a right to determine the law and the fact, under the direction of the court, as in other cases."25

During this period, English jurors were also insisting on their right to decide questions of law. The Crown repeatedly attempted to prosecute for libel; the Crown's judges tried to control jury verdicts. In one celebrated case, the judge told the jurors that because the defendant did not deny that he published the document in question and because the judge ruled as a matter of law that the document was libelous, the jurors were obliged to return a verdict of guilty. ${ }^{26}$ Such high-handed pressure tactics caused an uproar. In 1792, after much debate, Parliament passed Fox's Libel Act, ${ }^{27}$ which stated that the judge could explain the law to the jurors, but gave the jurors a choice of how to respond. The jurors could return either a special verdict, responding to each factual issue and leaving the law to the judge, or a general verdict, simply guilty or not guilty with no explanation of how the result was reached. The jury's right to decide matters of law moved in only one direction; they could decide that the law did not apply to a defendant when a judge thought it did, and

\footnotetext{
22. Life and Works of John Adams 253-55 (C.F. Adams ed. 1856).

23. Georgia v. Brailsford, 3 U.S. (3 Dall.) 1, 4 (1794).

24. Bingham v. Cabot, 3 U.S. (3 Dall.) 19, 32-33 (1795); 2 Wilson's Works $371-74$ (J. Andrews ed. 1895).

25. Ch. 75,1 Stat. 597 (1798).

26. The Dean of St. Asaph's Case, 21 Howell's State Trials 847, 869 (London 1816) (1st ed. London 1783).

27. See Sparf and Hansen v. United States, 156 U.S. 51, 134-40 (1895) (Gray, J., dissenting)
} 
their decision would be final. But if they decided that the law did apply when the judge thought it did not, the judge could set their decision aside. Because the jury could only mitigate the harshness of the law, and could not impose a harsher view of the law to convict an unsuspecting person, this limited view of the jury's right to consider the law as well as the facts did not raise any due process problems. This approach provides a model for modern jury nullification, which permits the jury to shift the law in only one direction-that of mercy.

\section{B. The Nineteenth Century Revision}

The jury's right to consider the equities of the law was sharply curtailed in the United States during the nineteenth century, in part because some leading judges did not think that a jury could be permitted to mitigate the law without also being able to create harsh and vindictive laws. Supreme Court Justice Joseph Story was the most forceful advocate of limiting the jury's function to fact-finding. In a case involving the transportation of slaves along the coast of Africa, defense attorneys argued that the jurors should be told they can judge the law as well as the facts. ${ }^{28}$ As trial judge, Story conceded that the jurors have the "physical power to disregard the law, as laid down to them by the court." Nonetheless, he did not think jurors' decisions should be based simply on their own notions or whims:

On the contrary, I hold it the most sacred constitutional right of every party accused of a crime, that the jury should respond as to the facts, and the court as to the law. It is the duty of the court to instruct the jury as to the law; and it is the duty of the jury to follow the law, as it is laid down by the court. This is the right of every citizen; and it is his only protection. If the jury were at liberty to settle the law for themselves, the effect would be, not only that the law itself would be most uncertain, from the different views, which different juries might take of it; but in case of error, there would be no remedy or redress by the injured party; for the court would not have any right to review the law as it had been settled by the jury ... Every person accused as a criminal has a right to be tried according to the law of the land ... and not by the law as a jury may understand it, or choose, from wantonness, or ignorance, or accidental mistake, to interpret it. ${ }^{29}$

Story's language is strong, but careful analysis of the case indicates that his reasoning does not apply to the current jury nullification debate, i.e., the right of the jury to refuse to apply the law. Justice Story was construing an 1820 statute that provided the dealth penalty for any American citizen who should "seize any negro or mulatto" with the intent of making the person a slave. The defendant had been a sailor on a ship that transported slaves from Portuguese Africa. According to Story, before the statute could be applied to the defendant's acts, two questions of interpretation had to be resolved:

28. United States v. Battiste, 24 F. Cas. 1042 (C.C.D. Mass. 1835) (No. 14,545).

29. Id. at 1043 . 
(1) whether the statute applied to sailors who gained no title over slaves and no profit from their sale; and (2) whether it applied to the transportation of slaves between two points within a country practicing slavery. Justice Story answered both questions no. Story's concern, in depriving the jurors of the power to interpret the law, was to prevent them from convicting and executing the defendant out of vengeance when he was inclined to be merciful. He was worried that the jury would punish the defendant for an act that the legislature did not intend to criminalize, rather than act mercifully and refuse to punish the violation of a statute.

Although Justice Story did not address specifically the jury's right to act mercifully, he apparently could not accept the seeming inconsistency of allowing a jury to reduce a punishment if it could not also increase it. He felt that if the jury's power to create laws was to be limited, its power to nullify them also had to be limited. Modern proponents of jury nullification would agree with the result reached by Justice Story in his case. A trial judge should decide questions of law, and a judicial ruling that the law does not apply to the accused cannot be reversed by the jury. The jury's power to "nullify" the law is simply a power to be merciful.

Justice Story's successor in the judicial campaign to limit jury freedom was Supreme Court Justice Benjamin R. Curtis. In 1851, Curtis was the trial judge in a slave case $^{30}$ involving a violation of the Fugitive Slave Act. ${ }^{31}$ This statute was obnoxious to a large part of the population and difficult to enforce because juries habitually acquitted in cases of obvious violation. The defendant's lawyer argued to the jury: "this being a criminal case, the jury were rightfully the judges of the law, as well as the fact." ${ }^{32}$ He continued, if any of the jurors believed the statute "to be unconstitutional, they were bound by their oaths to disregard any direction to the contrary which the court might give them." ${ }^{33}$

Justice Curtis interrupted the lawyer's argument and gave a long opinion rejecting his assertion. Unlike Story, Curtis was squarely confronted with the argument that the jury should be allowed to act mercifully to mitigate the effect of an unjust law. Like Justice Story, Curtis refused to consider that proposition alone, but he seemed to view the argument as something more-that the jurors should have total authority to pass on the law, with the power to increase as well as decrease the penalties to be imposed. Justice Curtis cited an 1802 congressional statute that said the decisions of the Supreme Court were final. ${ }^{34}$ He argued, if jurors were permitted to decide questions of law, then they could overturn decisions of the Supreme Court, the purpose of the 1802

30. United States v. Morris, 26 F. Cas. 1323 (C.C.D. Mass. 1851) (No. 15,815).

31. Ch. 113, \$ 4, 3 Stat. 600 (1820).

32. United States v. Morris, 26 F. Cas. at 1331.

33. Id.

34. Id. at 1334 . 
statute would be subverted, and uniform interpretations of the law would be impossible. ${ }^{35}$ This argument is inapplicable to the contentions of modern proponents of jury nullification. They do not ask that juries be allowed to reverse decisions of the Supreme Court, or even that any jury's decision should have any effect beyond the limits of the specific case. Their contention is that within one courtroom, with regard to one defendant and one set of facts, the impaneled jurors should be told that they have the discretion to mitigate the law's harshness if justice so requires.

The rulings of Justices Story and Curtis were widely examined throughout the country, but they were only decisions of individual judges and hence were only as influential as they were persuasive.

In 1895, the Supreme Court finally considered the question of what jurors should be told about their power. Quoting extensively from Story and Curtis, the Court agreed with their conclusions by a vote of seven-to-two. The case, Sparf and Hansen $v$. United States, ${ }^{36}$ involved two sailors accused of throwing a comrade overboard. The sailors were charged with murder; their defense was that what they did constituted the lesser offense of manslaughter. The defendants asked the trial judge to tell the jurors that it was within their power to return a verdict of either murder or manslaughter. The judge refused, saying no evidence had been introduced that would support a verdict of manslaughter. The judge conceded that it was within the power of the jury to return a verdict of manslaughter, but maintained that such a conclusion would not be legally defensible. In response to a request for additional instruction, the trial judge told the jurors:

In a proper case, a verdict for manslaughter may be rendered, . . . and even in this case you have the physical power to do so; but as one of the tribunals of the country, a jury is expected to be governed by law, and the law it should receive from the court. [emphasis deleted] ${ }^{37}$

The convicted defendants appealed to the Supreme Court, arguing that the jury had been improperly instructed. The lengthy majority opinion rejecting the appeal concludes that because jurors cannot be permitted to increase penalties or create laws on their own, they cannot be allowed to reduce such penalties or nullify laws. The reasoning parallels that of Justices Story and Curtis and fails to distinguish between jury vengeance and jury mercy.

Even though no one argued that the jury should be allowed to create its own crimes or to impose stiffer punishment than permitted by law, the Court was haunted by that specter:

[I]f a jury may rightfully disregard the direction of the court in matter of law, and determine for themselves what the law is in the particular case before

\footnotetext{
35. Id.

36. 156 U.S. 51 (1895).

37. Id. at 62 n.1.
} 
them, it is difficult to perceive any legal ground upon which a verdict of conviction can be set aside by the court as being against law. If it be the function of the jury to decide the law as well as the facts-if the function of the court be only advisory as to the law - why should the court interfere for the protection of the accused against what it deems an error of the jury in the matter of law. ${ }^{38}$

Thus, the majority opinion contains broad language limiting the jury's power, but it cannot be viewed as a holding rejecting the modern concept of jury nullification. First of all, the trial judge in Sparf told the jurors they had the "physical power" to return a verdict of manslaughter despite the evidence; ${ }^{39}$ the Supreme Court did not criticize that instruction. Second, the majority opinion argues forcefully that juries may not decide questions of law or create crimes. No modern jury nullification proponent would question either of these principles. It does not necessarily follow that juries must be deprived of the power to be merciful. ${ }^{40}$ Although the Sparf majority clearly did decide that jurors must take the law from the judge and may not substitute their own

38. Id. at 101 .

39. 156 U.S. at $62 \mathrm{n} .1$, quoted above in the text at note 37 .

40. Another aspect of Sparf also makes it inapplicable to the contemporary nullification position. From the facts of that case it is clear that the jury was considering a verdict of manslaughter, but evidence for that offense was lacking. The court instructed the jury to that effect. The Supreme Court was therefore simply upholding the principle that a jury cannot convict in the absence of evidence beyond a reasonable doubt. In order for the jury to lessen the penalty in Sparf, they would have to convict the defendant of a crime for which the defendant was not indicted. Even though the jury would have acted out of leniency, they would nevertheless be convicting against the evidence. Sparf concludes that they should be told they should not do this.

Support for this view of Sparf may be found in the recent case of United States ex. rel. Matthews v. Johnson, 503 F.2d 339 (3rd Cir. 1974), cert. denied sub nom. Cuyler v. Matthews, 420 U.S. 952 (1975), which involved the constitutionality of a practice allowing the jury to return a voluntary manslaughter verdict despite the absence of evidence. Pennsylvania case law permitted juries to convict for voluntary manslaughter in murder cases despite the lack of evidence of provocation or heat of passion. This rule was based upon two different considerations: (1) that voluntary manslaughter is a lesser-included offense of murder, and (2) "a realistic appreciation of the fact that factors such as sympathy or extenuating çircumstances may lead a jury to find a defendant guilty of the lesser included offense" (503 F.2d at 341) even though the evidence supports the greater verdict. Thus, Pennsylvania permitted a jury to do what Sparf had forbidden, i.e. convict for a lesser offense even though the evidence taken strictly would not support the conviction. The U.S. Court of Appeals for the Third Circuit upheld this practice in Matthews, but struck down as unconstitutional the unfettered discretion of the trial judge to refuse to instruct the jury as to this authority. According to the court, such discretion violates due process because it is arbitrary, it subjects similarly situated defendants to unequal protection of the law, and it removes from the jury the opportunity to consider another legitimate verdict.

Thus, in Pennsylvania, a judge is required, upon request of the defendant, to instruct the jury that it may convict for a lesser offense, despite the absence of evidence. The U.S. Court of Appeals for the Third Circuit approved the specific practice that had been disapproved eighty years earlier in Sparf and Hansen.

This same result has been reached in Indiana, where the court now permits juries to return verdicts of manslaughter when murder is charged, despite technical inadequacies in the evidence. See the text at notes 118-21, infra. (But cf., People v. Gottman, 64 Cal. App. 3d 775, 134 Cal. Rptr. $834,837(1977))$. 
beliefs of what the law should be, they did not address the specific question whether jurors should be told they can refuse to enforce the law's harshness when justice so requires. ${ }^{41}$ The Supreme Court has yet to address this issue directly, although the Court has recently reaffirmed the jury's lawmaking role in other contexts. ${ }^{42}$ Before looking at examples of approved jury lawmaking -and the Supreme Court's opinions supporting this role-we will survey the current views of lower-court judges who have discussed whether jurors should be told of their nullification power.

\section{Recent Judicial Attitudes Toward Jury Nullification}

For the first half of this century the controversy over jury nullification remained largely dormant. ${ }^{43}$ It began anew in the 1960 s in criminal cases involving political controversies. As the Department of Justice moved dramatically against antiwar activists, defense lawyers sought a legal means to allow the jurors, as the conscience of the community, to consider the morality of the defendant's actions. Although initially dismissed as historically unsound, functionally unwise, and legally untenable, the jury nullification argument has acquired important judicial and academic support in the last ten years.

41. Modern commentators do not disagree on the content of these historical precedents, but they do differ on the application of these precedents to the current controversy. Professor Gary $\mathrm{J}$. Simson has argued, for instance, that the power to acquit on the basis of conscience is a broader and more substantial power than the power to interpret the law. Simson, Jury Nullification in the American System: A Skeptical View, $54 \mathrm{~T}_{\mathrm{Ex}}$. L. Rev. 488, 506 (1976). The power of interpretation, he says, would be "a right on the jury's part to step into the judge's shoes." (Id.) but the power to nullify is analogous to the more substantial role of the legislator:

Like a legislature, a jury with a right to nullify defines blameworthy conduct according

to its own notions of justice. A judge's authority to "make law"-an essentially interstitial

or, in the case of common law, incremental operation-pales in comparison. Id. at 507.

Proponents of jury nullification view the matter differently. Jurors possessing the right to decide what the law is would appear to constitute a much greater threat to liberty than jurors who must take the law from the judge but are also told they may acquit on the basis of conscience in exceptional situations. In the former instance, a consistent body of law could not develop. Appellate courts could not review jury decisions because juries, having the authority to decide the meaning of law, could not erroneously apply it. See, e.g., F. Wharton, A Treatise on the Criminal Law of the United States 1119 (4th ed. Philadelphia 1857) (1st ed. Philadelphia 1856); United States v. Shive, 27 F. Cas. 1065 (C.C.E.D.Pa. 1832) (No. 16,278). A jury that is considering acquittal even though the facts indicate that the law has been broken is subject to many constraints, which we shall review later (see text at notes 220-32, infra).

Jury nullification proponents would argue that a jury that has the power to interpret the law is a jury that has the power to make law, thereby occupying a "legislative" role. On the other hand, a jury that acquits on the basis of conscience occupies a policy-making or prosecutorial role, acting not as a lawmaker but as a discretionary body deciding how to apply law.

Another problem with Professor Simson's analogies is that they appear to be equally applicable to the discretion exercised by prosecutors and police officers, who also occupy what he would term a "legislative" role. See text at notes $152-53$, infra.

42. See text at notes 90-110, infra.

43. But see Howe, supra note 8 . 
In 1971, the trial judges in Kansas approved the principle of jury nullification, and printed the following instruction in the official jury instructions as one that could-at the discretion of the judge, but not over the objections of the defendant-be given to juries in criminal cases:

It is presumed that juries are the best judges of fact. Accordingly, you are the sole judges of the true facts in this case.

I think it requires no explanation, however, that judges are presumed to be the best judges of the law. Accordingly, you must accept my instructions as being correct statements of the generally accepted legal principles that apply in a case of the type you have heard.

The order in which the instructions are given is no indication of their relative importance. You should not single out one or more instructions and disregard others but should construe each one in the light of and in harmony with the others.

These principles are intended to help you in reaching a fair result in this case. . . You should do just that if, by so doing, you can do justice in this case.

Even so, it is difficult to draft legal statements that are so exact that they are right for all conceivable circumstances. Accordingly, you are entitled to act upon your conscientious feeling about what is a fair result in this case and acquit the defendant if you believe that justice requires such a result.

Exercise your judgment without passion or prejudice, but with honesty and understanding. Give respectful regard to my statements of the law for what help they may be in arriving at a conscientious determination of justice in this case. That is your highest duty as a public body and as officers of this court. [emphasis added] $]^{44}$

In authorizing this instruction, the trial judges included "Notes on Use" as an explanation of its meaning. These Notes describe the instruction as a "more honest statement" of the jury's role than the traditional instruction that orders the jurors to adhere rigidly to the judge's explanation of the law:

Arguably, the above instruction should bring into play the underlying value of trial by jury: The application of community conscience. If extenuating circumstances make an otherwise culpable act excusable, a jury should feel empowered to so find. Community standards are more apt to be applied if the jurors are told they are free to do what, overall, seems right to them. [emphasis added] ${ }^{45}$

The Kansas instruction clearly recognized that nullification is a mercy doctrine permitting the jury to acquit despite a defendant's technical guilt. This nullification instruction was used only a few times; the Kansas Supreme Court disapproved it in $1973 .{ }^{46}$ Although the court recognized the power of the jury to return any verdict whatsoever, the court said, "power is one thing and

44. Pattern Instructions for Kansas 51.03, at 36 (1971); see F. Woleslagel, Jury 112-13 (National College of the State Judiciary, Reno, Nev., 1973). This instruction was declared to be inappropriate by the Kansas Supreme Court in the case of State v. McClanahan, 212 Kan. 208, 510 P.2d 153 (1973), see text at notes 46-48, infra.

45. 510 P.2d at 157; Pattern InStructions for Kansas, supra note 44 , at 37 ; F. WOleslagel, supra note 44 , at 113 .

46. State v. McClanahan, 212 Kan. 208, 510 P.2d 153 (1973). 
proper function and legal duty is another." 47 The crux of the court's opinion appears below:

The administration of justice cannot be left to community standards or community conscience but must depend upon the protections afforded by the rule of law. The jury must be directed to apply the rules of law to the evidence even though it must do so in the face of public outcry and indignation. Disregard for the principles of established law creates anarchy and destroys the very protections which the law affords an accused. ${ }^{48}$

The court appears to have misunderstood the purposes of the instruction, which does not authorize the jury to proceed lawlessly, but tries to impress upon the jurors, in as careful a fashion as possible, their role as the ultimate decision-makers on whether a general law can be equitably applied to a particular situation. Despite the Kansas Supreme Court's holding, the fact that the trial judges recognized the justice of giving a more honest guide to the jury in its deliberations, and fashioned instructions designed to support mercy and conscience, is a real victory for jury nullification.

Of even greater significance is United States $v$. Dougherty, ${ }^{49}$ the first modern case to discuss the jury nullification instruction at length and debate the wisdom of instructing the jurors about their power to nullify. In this case, nine members of the Catholic clergy broke into Dow Chemical Company offices and ransacked the premises to protest Dow's manufacture of napalm. The defendants, the "D.C. Nine," requested a jury nullification instruction at the trial, but the request was refused. On appeal, the U.S. Court of Appeals upheld, by a two-to-one vote, the trial judge's refusal to give the nullification instruction.

Judge Harold Leventhal wrote for the majority and conceded that " $[t]$ he pages of history shine on instances of the jury's exercise of its prerogative to disregard uncontradicted evidence and instructions of the judge,"50 specifically citing the Zenger case ${ }^{51}$ and the nineteenth century acquittals in fugitive slave cases. But then, after acknowledging the value of jury nullification, Judge Leventhal said he feared that " $[t]$ he way the jury operates may be radically altered if there is alteration in the way it is told to operate." $52 \mathrm{He}$ asserted that jurors already know of their power to nullify through "informal communication from the total culture," citing literature, television, newspa-

\footnotetext{
47. Id. at 214,510 P.2d at 158 .

48. Id. at 216,510 P.2d at 159 .

49. 473 F.2d 1113 (D.C. Cir. 1972) (the debate on jury nullification in Dougherty was not essential to the disposition of the appeal, because the issue of self-representation required the case to be returned to the trial court). This case is discussed in more detail in the text at footnotes 208-42, infra.

50. Id. at 1130 .

51. Id.; see text supra at note 21.

52. United States v. Dougherty, 473 F.2d at 1135.
} 
pers, conversations and readings of history. ${ }^{53}$ These informal sources convey the idea that jurors are free to depart from the judge's instruction in rare cases. But, according to Judge Leventhal's conclusion, what functions as an informal procedure might be unworkable if institutionalized.

Judge Leventhal suggests that we consider the analogy of speed limits. A posted speed limit of $60 \mathrm{mph}$ produces speeds of 10 or $15 \mathrm{mph}$ in excess of that limit. Some of this greater speed is tolerated, as motorists know, even though they are not officially told this. If the speed limit were raised to the speeds now tolerated, motorists would drive at even greater speeds, and the tolerance factor would have to be raised as well. Judge Leventhal then asks, “. . . can it be supposed that the speeds would stay substantially the same if the speed limit were put: Drive as fast as you think appropriate, without the posted limit as an anchor, a point of departure?"54 Judge Leventhal concludes that, in cases of high conscience, the jury will exercise its strong preference for freedom without being told to do so; but the jury should not be encouraged to deviate from the norm. Any other rule would make the juror feel "that it is he who fashions the rule that condemns."55

It is significant that Judge Leventhal does not define his concept of jury nullification. His speed limit analogy reveals that he is focusing on the question whether the jury can decide what the law is, rather than on the more modest question whether the jury can refuse to apply the law in specific situations. Jury nullification proponents would respond to his analogy by saying that speed limit signs should state that "the posted limit is $60 \mathrm{mph}$, but if emergency conditions exist, persons who drive faster may not be punished." Jury nullification does not ask the jury to make up the law, but permits the jury to recognize that specific departures from the law can be justified.

Chief Judge David Bazelon, in his dissenting opinion, condemns the inconsistent view that glorifies nullification as enhancing the "over-all normative effect of the rule of law," 56 while requiring that the nullification power be concealed from jurors and perhaps even denounced in their presence-as had been done in the Dougherty case. ${ }^{57}$ In Judge Bazelon's view, jurors should be told candidly that part of their job is to decide on the equity of applying the law in their particular case:

The [jury nullification] doctrine permits the jury to bring to bear on the criminal process a sense of fairness and particularized justice. The drafters of legal rules cannot anticipate and take account of every case where a defendant's conduct is "unlawful" but not blameworthy, any more than they can draw a bold line to mark the boundary between an accident and negligence.

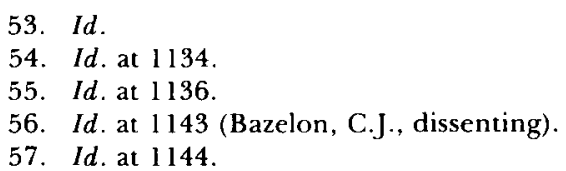


It is the jury-as spokesman for the community's sense of values-that must explore that subtle and elusive boundary.

... The very essence of the jury's function is its role as spokesman for the community conscience in determining whether or not blame can be imposed. ${ }^{58}$

Both the majority and dissenting opinions in Dougherty recognize the value of the jury's power to nullify, but they disagree over whether the jury should be told about its power. Judge Leventhal fears that a specific jury instruction will upset the delicate balance that reserves nullification for cases truly requiring it. On the other hand, Judge Bazelon believes that jurors will not revolt simply because they are told of their nullification power, because many internal restraints keep juries from acting irrationally. Modern debate over jury nullification is shaped by the difference of opinion on this vital issue.

Another important judicial convert on the nullification instruction is U.S. District Judge Frank A. Kaufman of the District of Maryland. ${ }^{59}$ He admits that he originally opposed giving the nullification instruction and advised against it in a Vietnam protest case. ${ }^{60}$ By the late 1970 s, however, his views had changed. Maryland is one of the states that gives a nullification instruction in its state courts, ${ }^{61}$ and Judge Kaufman may have been influenced by the smooth operation of the system he saw in nearby courts. The most significant influence, however, was the issue of a defendant's right to self-representation. After the Supreme Court ruled that all defendants have the right to represent themselves, ${ }^{62}$ Judge Kaufman felt that candor and honesty required that jurors be told of their power to nullify in appropriate cases. The defendant acting without an attorney will inevitably appeal to the jurors' sense of justice, and the constraints a trial judge has over such defendants will inevitably be less than the power a judge has over an attorney. ${ }^{63}$ Judge Kaufman argues that it is preferable to instruct a jury clearly about its power ${ }^{64}$ rather

58. Id. at 1142 (Bazelon, C.J., dissenting).

59. Kaufman, The Right of Self-Representation and the Power of Jury Nullification, 28 CASE W. RES. L. REv. 269 (1978).

60. Id. at 283-84. Judge Kaufman reports that he was consulted regarding U.S. District Judge

Roszel C. Thomsen's refusal to give the nullification instruction in the case of United States $v$.

Moylan, 417 F.2d 1002 (4th Cir. 1969), cert. denied, 397 U.S. 910 (1970).

61. See text at notes 127-45, infra.

62. Faretta v. California, 422 U.S. 806 (1975).

63. Kaufman, supra note 59, at 281-82.

64. Judge Kaufman recommends that jurors be instructed "along the following lines:"

.. (1) in a democracy, the way to change a law is not to violate it, whether by passive, non-violent, or any other means, but instead by expression of views at the polls and otherwise; (2) a juror should never fail to enforce a law as defined in the judge's instructions unless the very roots of his conscience and his very guts will not permit him to do so; (3) a juror should never act out of bias, prejudice or sympathy; (4) a juror should rarely, except in that once in a lifetime type of case when he just cannot permit himself Id. at 286 . to do otherwise, reject and fail to follow the court's instructions on the law. 
than force the jury to guess about its role in weighing the justice of enforcing a law. Although not every case warrants the nullification instruction, he concludes, "fairness and candor demand that judges should have the flexibility to provide for a nullification instruction in appropriate cases." 65

Fairness and candor are thus at the heart of today's debate on jury nullification. Should the jury be told of its nullification power so it can exercise it wisely, or should we keep jurors mystified, hoping they will exercise the power in extreme cases but withholding from them a full explanation of their responsibilities? Before reviewing how jury nullification works in states that use it, we will review the lawmaking power of juries in other contexts.

IV

\section{The Lawmaking Power of Juries in Other Contexts}

One of the reasons some judges acknowledge the need for a formal jury nullification instruction is their recognition that they instruct jurors in a number of other contexts that the jurors should serve as the community's conscience and determine what conduct is reasonable and appropriate in the situation they are judging. We frequently ask jurors to make law when we ask them to compare the litigants' conduct to that of a "reasonable person." When jurors are asked to determine "malice" or "self-defense," we are asking them to weigh the reasonableness of the accused's activity, and, in that sense, to make law.

In the vast majority of civil and criminal trials, most judges instruct the jury that they are the finders of fact and must take their understanding of the law from the judge. That instruction divides the jury (the fact-finder) from the judge (the law-giver). Although simple to state, this division is, in the words of Sir Patrick Devlin, "quite misleading." of adjudication are rarely so simple that the law/fact dichotomy can be made with ease. ${ }^{87}$ The disagreement is usually complex and the product of conflicting sets of understanding and experience. For this reason juries are asked to weigh the evidence, sift the information, judge the credibility of witnesses, and reach a general verdict applying those "facts" to the law. The constitutional requirement that the jury be selected from a representative cross section of the community is essential because segments of the community differ in their perceptions, and because all viewpoints are entitled to be heard. ${ }^{68}$ Jurors bring a variety of perspectives to their deliberations that enables them to see beyond the single viewpoint of the judge. The jury verdict may thus act as a social barometer that measures the community response to the legal

\footnotetext{
65. Id. at 269 .

66. P. Devlin, Trial by Jury 150 (1956).

67. See generally Kershen, Vicinage, 30 OKLA. L. REv. 1. 79-85 (1977).

68. See generally id. and J. VAN Dyke, JURy SElection, supra note 2, at 45-83.
} 
system. Jury verdicts provide significant information about the harmony, or lack thereof, between the laws and the people. This information, when fed back to the legal system and to the community, can serve to bring the law and its administration in line with popular sentiment and can act as a reliable guide for citizens seeking to order their affairs in accordance with the law.

All of this is old learning. The important point is not simply that jurors have discretion because the law/fact dichotomy is unclear, but that jurors are often expressly authorized by the legal system to engage in lawmaking and policy-deciding. ${ }^{69}$ Although jurors are frequently told that their role is to find the facts and apply the law to those facts, in reality the legal system counts on them to do much more.

\section{A. The Civil Jury}

A trial judge will send a case to the jury only if reasonable persons could disagree on how the factual issues are to be resolved. If the jury could legitimately decide the case in favor of either party, it is clearly being asked to do more than apply reason to the evidence-it is being asked to use its intuition and instincts to decide which result is the "right" one. ${ }^{70}$ In so acting, the jury is in effect making policy or declaring law-at least for the case at hand. Civil jurors, in struggling with the factual issues, must often decide how the parties ought to have acted, or how a reasonable person would have acted, under the circumstances. This judgment requires a policy decision-not just an evaluation of the facts.

Professor Harry Kalven noted that the civil jury is "the 'expert' tribunal for the two great distinctive issues posed by the common law: drawing the profile of negligence and handling the individual pricing of damages." 71 The reason we entrust the calculation of damage to the jury has been explained by federal Judge Charles Wyzanski of Boston: "[T]he estimate of what loss the plaintiff suffered can best be made by men who know different standards of working and living in our society." 72 Judge Hogan has observed on the ques-

69. The jury historically functioned not only as fact finder but as a tempering element in criminal prosecutions. As Mr. Justice Nix observed in his Opinion in Support of Affirmance in Commonwealth v. Jones, [457] Pa. [563, 568-70], 319 A.2d 142, 146 (1974), [cert. denied 419 U.S. 1000], the capacity of the jury to find voluntary manslaughter even without evidentiary support derives particularly from its "historically recognized mercy dispensing power." [457 Pa. at 572, $319 \mathrm{~A} .2 \mathrm{~d}$ at 148] The absence of a logical basis for a voluntary manslaughter charge is thus not conclusive of the issue.

United States ex rel. Matthews v. Johnson, 503 F.2d 339, 350 n.6 (3rd Cir. 1974) (Adams, J., concurring), cert. denied sub nom. Cuyler v. Matthews, 420 U.S. 952 (1975).

70. Michael, The Basic Rules of Pleading, 5 Rec. A.B. City N.Y. 199-200 (1950). Protessor Michael considered the jury function to be more "emotional" than rational. He did not specifically mention or notice the lawmaking function involved.

71. Kalven, The Dignity of the Civil Jury, 50 VA. L. REv. 1055, 1058 (1964). See also, P. Devi.IN, supra note 66 , at $142-43$.

72. Wyzanski, A Trial Judge's Freedom and Responsibility, 65 HARv. L. REv. 1281, 1287 (1952). 
tion of damages that the representative character of the jury serves as a balance where "one juror may be a tightfisted penny-pincher, [while] another freely spends money so long as it is not his own."

One area of civil tort law especially prone to jury lawmaking is the defense of contributory negligence. This defense is disliked because it often produces harsh consequences; juries have tried to ameliorate its impact by reaching compromise verdicts. Although disapproved in theory, these verdicts are often applauded in practice. In Karcesky $v$. Laria ${ }^{74}$ conflicting evidence was presented concerning the plaintiff's contributory fault. The jury favored the plaintiff, but awarded minimal damages. The plaintiff appealed and the Pennsylvania Supreme Court recognized the value of what the jury had done:

The doctrine of comparative negligence ... is not recognized by the Courts of Pennsylvania, but as a practical matter [it is] frequently taken into consideration by a jury. The net result, as every trial judge knows, is that in a large majority of negligence cases where the evidence of negligence is not clear, ... the jury brings in a compromise verdict ....

Where the evidence of negligence or contributory negligence, or both, is conflicting or not free from doubt, a trial judge has the power to uphold the time-honored right of a jury to render a compromise verdict. ${ }^{75}$

In such cases the jury "makes law," and in a civil case, a trial judge or appellate court could overturn the verdict for that reason. Refusal to do so is proof that the jury is valued precisely because it can soften the law where such softening is necessary for justice. Because the jury can do what the judge cannot, the jury is encouraged to exercise its mercy powers. When the jury does, courts do not always strictly enforce the law/fact distinction.

Judges' recognition of jury compromise in contributory negligence cases is not at all surprising. The doctrine of contributory negligence was developed as a jury control mechanism to protect infant industries from liability in the opening decades of the Industrial Revolution. ${ }^{76}$ Despite the doctrine, which many commentators and judges believe to be overly harsh and unfair, juries have continued to apply a rough sense of justice within the confines of the discretion they are afforded. The recent legislative trend towards comparative negligence attests to the wisdom of what juries had been doing all along.

Naturally, the law-dispensing function of the jury has its costs. To the extent that the composition of individual juries changes, different results may be expected. The certainty and predictability of the law may decrease somewhat. This cost is not excessive; it is a necessary corollary of encouraging juries to

\footnotetext{
73. Hogan, Some Thoughts on Juries in Civil Cases, 50 A.B.A.J. 752, 753, (1964).

74. 382 Pa. 227, 114 A.2d 150 (1955).

75. 382 Pa. at $234-35,114$ A.2d at 154 .

76. See W. Prosser, Torts 418 (4th ed. 1971); Maloney, From Contributory to Comparative Negligence: A Needed Law Reform, 11 U. FlA. L. Rev. 135, $144-45$ (1958); Powell, Contributory Negligence: A Necessary Check on the American Jury, 43 A.B.A.J. 1005 (1957).
} 
evolve standards of community tolerance. To keep the law from becoming too rigid and from losing touch with the society it regulates,-some method for achieving flexibility is necessary.

\section{B. The Criminal Jury}

The jury's lawmaking role in criminal cases is more pronounced than in civil cases. If juries were restricted to finding facts, cases with no disputed factual issues would be withheld from the jury. But such cases are presented to the jury. ${ }^{77} \mathrm{By}$ its general verdict of innocence, the jury may free a person without its verdict being subject to challenge. The judge cannot ask jurors to explain their verdict, nor may the judge punish the jurors for it. Although judges now generally tell jurors they must obey the judge's instructions on the law, the jurors may not be compelled to do so. If the jury convicts, however, the defendant is entitled to a broad range of procedural protections to ensure that the jury verdict was fair and honest.

When a jury acquits a defendant even though he or she clearly appears to be guilty, the acquittal conveys significant information about community attitudes and provides a guideline for future prosecutorial discretion in the enforcement of the laws. Because of the high acquittal rate in prohibition cases during the 1920s and early 1930s, prohibition laws could not be enforced. The repeal of these laws is traceable to the refusal of juries to convict those accused of alcohol traffic. Even today, jury acquittals are numerous in cases involving liquor laws and drunk driving, because the jury members may be too "close to the conduct they are asked to judge."78

Juries have been able to "make" law in criminal settings by exercising their veto power over enforcement of unjust laws and just laws in unjust circumstances. At the beginning of the nineteenth century in England, persons convicted of violating any one of over 230 crimes were automatically sentenced to death. ${ }^{79}$ Jurors refused to convict because, although they recognized the defendant's conduct as criminal, they could not condemn someone to death for an offense that they felt did not warrant such a penalty. In London, not only did jurors petition to be relieved of being accessory to "judicial murder," but also bankers petitioned to abolish capital punishment for forgery because the penalty prevented convictions "and thus endanger[ed] the property which it [was] intended to protect." 80 Jury acquittals also contributed to the downfall

77. See United States v. Davis, 413 F.2d 148 (4th Cir. 1969), and United States v. Fielding, 148 F. Supp. 46 (D.D.C. 1957), rev'd on other grounds, 251 F.2d 878 (D.C. Cir. 1957). A judge cannot direct a verdict of guilt in such cases. See Commonwealth v. Archambault, 448 Pa. 90,290 A.2d 72 (1972)

78. H. Kalven \& H. Zeisel, supra note 10, at 293.

79. Id. at 311 n.7.

80. L. Radzinowicz, a History of English Criminal Law and Its Administration from 1750 (1948), quoted in United States v. Dougherty, 473 F.2d at 1136 n.53. Note also the following 
of the colonial Embargo Law, the Fugitive Slave Act, and the laws governing the crime of seditious libel. Very few would argue that society is worse off because of this jury action.

Discussion of the jury as lawmaker in criminal cases must not be misunderstood. The jury does not have the authority to make laws that will govern other cases. Only once in our history was such an idea seriously suggested. In Commonwealth v. Sullivan, ${ }^{81}$ the Supreme Judicial Court of Massachusetts faced the question whether a particular game was a lottery within the meaning of a criminal statute. Speaking for the court, Justice Oliver Wendell Holmes, Jr. concluded that it was, because another jury had convicted a defendant who had operated a similar game. Holmes considered the earlier conviction a decision that the game was a lottery and he thought that the law had been settled by the earlier jury. Holmes said that "it is not necessary to go on forever, tak-

analysis from W. Forsyth, History of Trial By JURy 367-68 (2d ed. 1971), quoted in Furman v. Georgia, 408 U.S. 238, 245 n. 8 (1972) (Douglas, J., concurring):

When in respect of any class of offenses the difficulty of obtaining convictions is at all general in England, we may hold it as an axiom, that the law requires amendment. Such conduct in juries is the silent protest of the people against its undue severity. This was strongly exemplified in the case of prosecutions for the forgery of bank-notes, when it was a capital felony. It was in vain that the charge was proved. Juries would not condemn men to the gallows for an offense of which the punishment was out of all proportion to the crime; and as they could not mitigate the sentence they brought in verdicts of Not Guilty. The consequence was, that the law was changed; and when secondary punishments were substituted for the penalty of death, a forger had no better chance of an acquittal than any other criminal. Thus it is that the power which juries possess of refusing to put the law in force has, in the words of Lord John Russell, been the cause of amending many bad laws which the judges would have administered with professional bigotry, and above all, it has this important and useful consequence, that laws totally repugnant to the feelings of the community for which they are made, can not [sic] long prevail in England. [emphasis added]

Blackstone referred to the practice of jurors to understate the value of stolen goods so defendants could avoid the death penalty for minor thefts as "pious perjury." $4 \mathrm{~W}$. BLACKSTONE, Commentaries 238; see also W. R. Cornish, The Jury 129 (1968). A North American example of this phenomenon occurred in State v. Bennet, 3 Brevard 514 (S.C. 1815), where a jury found the defendant guilty of petty larceny rather than the capital offense of grand larceny. This verdict was possible only by disbelieving the sworn testimony of all the witnesses as to the value of the property stolen. On appeal, the right of the jury to find facts against the evidence was upheld. A more recent example is People v. Gottman, 64 Cal. App. 3d 775, 134 Cal. Rptr. 834 (1976) where a jury found an act of oral copulation to be consensual despite all evidence to the contrary.

Professor Lawrence Friedman has defended the jury's inclination to find facts consistent with the equities of the case:

This type of behavior has been called jury lawlessness; but there is something strange in calling lawless a power so carefully built into law. Jury power meant that a measure of penal 'reform' could take place without formal change in legal institutions. Jerome Hall has suggested that, as social attitudes towards criminals and crime begin to change, the changes first appear in the administration of criminal justice; penal 'reform'-enacted laws and new rules-follows as a 'ratification of practices' already developed.

L. Friedman, A History of American Law 252 (1973). The reference to Jerome Hall is to J. Hall, Thert, Law, and Society 140 (2d ed. 1952).

81. 146 Mass. 142, 15 N.E. 491 (1888). 
ing the opinion of the jury in each new case that comes up." 82 In his view, as juries rendered verdicts on factual questions, these facts would become matters of law. The jury would thus have a substantial opportunity to make law.

Holmes's view has not prevailed, and as the law now stands, the ability of a jury to make law that governs other cases is minimal. At best, a succession of jury verdicts can convince a prosecutor not to pursue certain cases or a legislature to rewrite or repeal a certain law. Consider, for example, the conduct of juries in some San Francisco cases several years ago. The San Francisco Police Department escalated its anti-prostitution efforts by decoying female police officers in "clinging" outfits on city street corners. These women were "wired for sound" and were authorized to arrest men proposing illicit sex with them. In the first court cases about this practice, juries acquitted after little deliberation. Interviews with the jurors revealed that the acquittals were based on a belief that the police practice constituted entrapment. ${ }^{83}$ The practice soon stopped. The jury once again made law. The police tried to enforce the prostitution laws and the prosecutor was compelled to bring the cases. The judges would not dismiss the charges. It was left to the jury to bring the community conscience to bear on the issue. The jury verdicts were not necessarily votes in favor of prostitution, but they did express popular concern over police practices and victimless crimes.

State $v$. Morse ${ }^{84}$ a case involving indecent assault upon a minor, expressly recognizes the necessity of the jury to exercise its function as the community's conscience. The defendant argued a reasonable mistake of fact concerning the girl's age, but the court held that the statute did not provide for such a defense. The court noted:

There may be cases where an application of [the statute] leads to an unjust result. This is not one of them. In fact situations where the underage female is the aggressor and her male partner the real victim, it is likely that the good judgment of prosecutors and jurors will prevent a miscarriage of justice. [emphasis added $]^{85}$

It is difficult to find a more express recognition of the value of the nullification power to save the law and the court from doing an injustice to the defendant. Courts depend on juries to do the right thing, even when it involves nullification of the judge's instruction. Because of the jury's unique nature, composed of lay people drawn from the entire community and accountable only to themselves for their verdict, the jury is free to act as a moral arbiter of disputes that cannot be resolved satisfactorily by other legal officials.

82. Id. at $145 ; 15$ N.E. at 494 .

83. O'Brien, Police Vice Traps Lose in Court Tests, San Francisco Sunday Examiner \& Chronicle, May 20, 1973, at B4, col. 1 .

84. 281 Minn. 378, 161 N.W.2d 699 (1968).

85. Id. at 385,161 N.W. $2 \mathrm{~d}$ at 703 . 
Euthanasia is another highly publicized crime that prosecutors are compelled to bring to court and judges are compelled to send to juries, even though both know and generally hope that juries will probably acquit. ${ }^{86}$ In this ritual, the letter of the law may be preserved without sacrificing justice in the process.

Judicial support or recognition of jury nullification has many forms. In a 1949 case decided by the U.S. Court of Appeals for the Ninth Circuit, ${ }^{87}$ the court noted how the jury system has survived intimidation by judges, the government, and even popular violence. In "flagrant" cases, according to the court, "the jury has always exercised the pardoning power, notwithstanding the law, which is their actual prerogative." [emphasis added] ${ }^{88}$ The fact that the jury did not nullify in that particular case was, in the court's view, further proof that the defendant's conviction should be upheld. In other words, the court said that if the defendants were truly the victims of injustice, the jury would have nullified. ${ }^{89}$ Its failure to do so supported the conviction.

86. Shenker, Euthanasia: Two New Cases to Consider, N.Y. Times, July 1, 1973, 44 (Editorials), at 3, col. 1. For recognition that juries often acquit in euthanasia cases and that the legal system has not fully adjusted to a clear policy on this crime, see Kutner, Due Process of Euthanasia: The Living Will, A Proposal, 44 IND. L.J. 539 (1968-69); and Sher, Legal Aspects of Euthanasia, 36 Albany L. Rev. 674 (1972). One judge, sitting without a jury, released a defendant in a euthanasia case reasoning that juries traditionally acquit in such cases. Crim. No. 58-3636 (Cook Co., Ill. 1958), discussed in Williams, Euthanasia and Abortion, 38 U. Colo. L. Rev. 178, 184-87 (1966). Charles Curtis, in his book, IT's Your LAW (1954) observes:

The jury has the function of making exceptions. We are rule-ridden. Juries relieve the judge of the embarrassment of making the necessary exceptions. They do this, it is true, by violating their oaths, but this, I think, is better than tempting the judge to violate his oath of office....

Euthanasia is one example of exceptional cases. The law recognizes that it incapable of dealing with euthanasia directly and candidly. So the law handles these killings deviously, or better, disingenuously. Lacking itself the genius to cope with them, the law turns them over to a jury, puts the jury on oath to decide according to the evidence, and at the same time takes pains to set no penalty on the jurors if they break their oaths. [emphasis added]

Id. at 94 .

See also Ingber, $A$ Dialectic: The Fulfillment and Decrease of Passion in Criminal Law, 28 RuTGERS L. Rev. 861,933 n.344 (1975). Professor Ingber discusses jury nullification at pages $932-37$ and concludes that "the jury's prerogatives should be retained." Id. at 937

87. Local 36 of Int'] Fishermen \& Allied Workers of America v. United States, 177 F.2d 320 (9th Cir. 1949).

88. Id. at 339 .

89. [I]n flagrant instances, the jury has always exercised the pardoning power, notwithstanding the law, which is their actual prerogative. This feature is of more importance here, since the jury, notwithstanding the arguments regarding economic oppression, did not see fit to acquit appellants... . U]uries which reflect common sense and the sentiment of local communities do, in fact, modify the doctrine of law. Such a process is still going on. [emphasis Id. added]

Another Ninth Circuit panel supported the lawmaking role of the jury a few years earlier. As the majority observed in Morris v. United States, 156 F.2d 525, 530 (9th Cir. 1946), "Juries do, however, have decisions to make that are not wholly factual." 


\title{
C. The U.S. Supreme Court's Recent Views on the Jury's Lawmaking Role
}

The Supreme Court has been silent on the nullification instruction ${ }^{90}$ since Sparf and Hansen.$^{91}$ However, in a number of recent cases the Court has recognized the jury's role as the community's conscience and its importance in bringing common sense to the interpretation of technical laws. In the 1968 case of Duncan $v$. Louisiana, ${ }^{92}$ the Court ruled that the U.S. Constitution requires states to provide jury trials for all defendants facing a possible punishment of six months or more. The justification for this ruling was not that jurors are more efficient or more reliable as finders of fact than judges, but rather that they bring the community's common-sense approach to the matter and can mitigate the harshness of the law in appropriate cases. The key passage in Justice Byron $\mathrm{R}$. White's majority opinion provides a persuasive argument favoring jury nullification:

\begin{abstract}
A right to jury trial is granted to criminal defendants in order to prevent oppression by the Government. Those who wrote our constitutions knew from history and experience that it was necessary to protect against unfounded criminal charges brought to eliminate enemies and against judges too responsive to the voice of higher authority. The framers of the constitutions strove to create an independent judiciary but insisted upon further protection against arbitrary action. Providing an accused with the right to be tried by a jury of his peers gave him an inestimable safeguard against the corrupt or overzealous prosecutor and against the compliant, biased, or eccentric judge. If the defendant preferred the commonsense judgment of a jury to the more tutored but perhaps less sympathetic reaction of the single judge, he was to have it. Beyond this, the jury trial provisions in the Federal and State Constitutions reflect a fundamental decision about the exercise of official power-a reluctance to entrust plenary powers over the life and liberty of the citizen to one judge or to a group of judges. Fear of unchecked power, so typical of our State and Federal Government in other respects, found expression in the criminal law in this insistence upon community participation in the determination of guilt or innocence. [emphasis added] ${ }^{93}$
\end{abstract}

Justice White did not say specifically what the jury should be told about its responsibilities, but one cannot help but feel that he was imagining that a rep-

90. The Supreme Court has specifically recognized, with apparent approval, the jury's power to nullify. In Morissette v. United States, 342 U.S. 246, 276 (1952), the Court concluded its opinion with the following language:

Had the jury convicted on proper instructions it would be the end of the matter. But juries are not bound by what seems inescapable logic to judges. . . They might have refused to brand Morissette as a thief. Had they done so, that too would have been the end of the matter.

Express approval of the pardoning power is also found in United States v. Dotterweich, 320 U.S. 277, 285 (1943), involving strict criminal liability. Noting that hard cases may arise under this doctrine, the Court observed, "the good sense of prosecutors, the wise guidance of trial judges, and the ultimate judgment of juries must be trusted." [emphasis added]. The Court was not referring to the jury's fact-finding role.

91. Sparf and Hansen v. United States, 156 U.S. 51 (1895); see discussion of this case in text at notes $36-40$, supra.

92. 391 U.S. 145 (1968).

93. Id. at 155-56. 
resentative jury might well have exercised the nullification power. The Duncan case involved a nineteen-year-old black who was given a sixty-day jail sentence because he jostled a white teenager after a discussion in which the black youth attempted to act as peacemaker between whites and blacks.

A second 1968 Supreme Court decision, Witherspoon v. Illinois, ${ }^{94}$ confirmed that the Court was acutely aware of the jury's role as community conscience, and wanted to strengthen it. Witherspoon was sentenced to death by a jury from which, in accordance with an Illinois statute, all persons who harbored any doubt over imposing the death penalty were excluded..$^{95}$

The Court declared this procedure unconstitutional, a violation of Witherspoon's right to due process of law, because Illinois had impaneled a "hanging jury" and thus "stacked the deck" against the defendant. ${ }^{96}$ The Court opinion suggests that it views the jury's essence as the ability to express its commonsense judgment, subject to each juror's willingness to pay respectful attention to the law as ordained by the legislature and as explained by the court. The Court said:

$[O]$ ne of the most important functions any jury can perform in making such a selection [between life and death] is to maintain a link between contemporary community values and the penal system - a link without which the determination of punishment could hardly reflect "the evolving standards of decency that mark the progress of a maturing society." [emphasis added] ${ }^{97}$

94. 391 U.S. 510 (1968).

95. The Illinois statute said the judge should excuse every juror who states that "he has conscientious scruples against capital punishment, or that he is opposed to the same." (391 U.S. at 512 , quoting 11l. Rev. Stat. ch. $38, \S 743$ (1959); that section was not specifically repeated in the Code of Criminal Procedure of 1963, but the Illinois Supreme Court has held that $\$ 743$ is incorporated into Ill. Rev. Stat., ch. 38, $\$ 115-4(d)$ (1967), which states that "[e]ach party may challenge jurors for cause.")

96. Id. at 523 .

97. $I d$. at 519 n. 15 .

The right of a jury to express community values and to temper the strict rule of law has been considered relevant not only in the determination of guilt, but also in the selection of penalty in a capital case. However, a Florida death penalty statute that permits a trial judge to impose death after a jury penalty verdict of life imprisonment raises the issue of the jury's inherent power in a criminal proceeding to decide for the accused despite the letter of the law. Florida Code, Section 921.141 (1977).

Under Florida law, after a person has been convicted of a capital offense there is a separate jury hearing on penalty, with a majority verdict necessary for life or death. The trial judge may reverse a verdict for either life or death but the Florida Supreme Court reviews all death sentences.

In Tedder v. State, 322 So. 2d 908 (Fla. 1975), the Florida Supreme Court said that in order to sustain a death sentence after a reversal of a jury life verdict "the facts . . . should be so clear and convincing that virtually no reasonable person could differ." Id. at 910. Justice Arthur England, concurring in the later case of Chambers $v$. State, 339 So. 2d 204 (Fla. 1976), explained that the purpose of overturning verdicts of life was "to insure the jury's adherence to law" and to prevent an "impassioned and unreasoned" decision to spare a defendant's life. Thus, the power to nullify is central to the constitutionality of the Florida procedure.

The U.S. Supreme Court, in Witherspoon v. Illinois, 391 U.S. 510 (1968), applied the sixth amendment to the penalty decision in a capital case by barring the broad use of challenges for 
The Court did not pursue this issue further, but it seems logical-if the jury is to maintain this link-to tell jurors that they have the authority to reject judicial instructions when they conflict with community values. ${ }^{98}$

In 1971, the Supreme Court explicitly acknowledged the importance of jury nullification in shaping law. The case challenged the constitutionality of the death penalty. In explaining why many states left the question whether to impose the death penalty to the jury, the Court noted that juries were already making such decisions by refusing to convict in cases with sympathetic defendants or mitigating circumstances:

cause to eliminate those with scruples against death. Obviously the Florida procedure serves precisely the end condemned in Witherspoon: to obtain a death sentence where "the law" requires it, despite the reluctance of a fairly-chosen jury to impose it. Thus, Witherspoon logically protects the sixth amendment integrity of a capital penalty jury (including the power to "nullify" for life), even though the states may be free to exclude jury participation in capital sentencing.

Presnell v. Georgia, 439 U.S. 14 (1978), suggests another challenge to the Florida procedure under the due process clause of the fourteenth amendment by holding that "fundamental principles of procedural fairness apply with no less force at the penalty phase of a trial in a capital case than they do in the guilt-determining phase of any criminal trial," $I d$. at 16. The earlier case of Gregg v. Georgia, 428 U.S. 153 (1976), noted that any attempt in a trial of guilt to override "the discretionary act of jury nullification" would be "of course . . totally alien to our notions of criminal justice." [emphasis added]. Id. at 199 n.50. Therefore, what would be "totally alien" in determining guilt may not be permitted in choosing life or death.

Another rationale for rejecting the Florida procedure on either sixth or eighth amendment grounds is suggested by McGautha v. California, 402 U.S. 183 (1971), and by the views of Justices Douglas, Burger and Powell in Furman v. Georgia, 408 U.S. 238 (1972). These opinions hold that jury nullification has been crucial in the restrained application of the death penalty according to "evolving standards of decency." The Florida practice of overruling life verdicts aborts this process of evolution in the bud.

At present there are at least twenty-six persons in Florida under sentence of death after jury verdicts of life. Cases presenting constitutional challenges to death sentences after life verdicts pending in the Florida Supreme Court are Phippen v. State (FSC Case No. 54, 664); Porter v. State (FSC Case No. 55, 841); and Johnson v. State (Case No. 56, 167). In Douglas v. State, 373 So.2d 895 (Fla. 1979), the Court rejected a fifth amendment double jeopardy argument. As of December, 1979, that decision was on appeal in the habeas corpus action of Douglas v. Wainwright, No. 79-775-Civ.T.K. (M.O. Fla.). The lives of these people are now linked to the survival of the jury as we know it.

We gratefully acknowledge the advice and assistance of Margo Paula Schulter of San Francisco for compiling the information on the Florida statute.

98. Justices Black and White, in their dissenting opinion, criticized the Court for ignoring the decision made by the Illinois Legislature that a jury in a capital case should be biased toward capital punishment, and argued that the jury should not be encouraged to nullify the legislature's decision (391 U.S. 535-40, at 541-42). It is conceivable that the majority did mistakenly fail to consider the intent of the Illinois Legislature, but it is much more likely that they believed it to be unconstitutional for a legislature to deprive a jury of its power to nullify, because such a power is inherent in the American concept of a jury.

The Court's majority opinion tempered the jury's power of nullification somewhat by demanding that each juror be willing at least to consider imposing the penalty desired by the legislature and by allowing the exclusion of those prospective jurors who had formulated a firm and unyielding determination to disobey the law. (391 U.S. at $522 \mathrm{n.21}$ ). Only Justice William O. Douglas would have gone one step further and said that even those persons unalterably opposed to the death penalty should be allowed to participate in the determination of whether the death penalty should be imposed. (391 U.S. at 528). See generally Note, Trial by Jury in Criminal Cases, 69 Colum. L. Rev. 419, 419-32 (1969). 
In order to meet the problem of jury nullification, legislatures did not try, as before, to refine further the definition of capital homicides. Instead they adopted the method of forthrightly granting juries the discretion which they had been exercising in fact. ${ }^{99}$

Still more recently, in 1974, the Court again acknowledged the lawmaking function of the jury. The Court stated that it was appropriate to allow the jurors to decide-based solely on their individual knowledge and experiences - what constitutes the contemporary community standards of obscenity. ${ }^{100}$

The Supreme Court has clearly refused to confine the jury to a factfinding role and has, in recent years, specifically acknowledged the role of the jury as a repository of community wisdom and as a lawmaking body. The jury brings community standards to bear on any number of legal questions, and the act of refusing to convict some defendants in special circumstances is consistent with that role. One final case that illustrates this view is the 1975 case of Taylor $v$. Louisiana. ${ }^{101}$ The Court faced the question of whether a male criminal defendant had standing to challenge a state statute that excluded women from jury service except those who had filed a written declaration of their interest in serving. The Court held that the defendant had standing and struck down the law as discriminatory, once again affirming its commitment to the jury:

The purpose of a jury is to guard against the exercise of arbitrary power-to make available the commonsense judgment of the community as a hedge against the overzealous or mistaken prosecutor and in preference to the professional or perhaps overconditioned or biased response of a judge. ${ }^{102}$

Justice White's opinion for the Court pointed out that this purpose could hardly be served if distinctive groups in the community were excluded from jury service: "Community participation in the administration of the criminal law ... is not only consistent with our democratic heritage but is also critical to public confidence in the fairness, of the criminal justice system."103 Citing and approving the Federal Jury Selection Act of $1968^{104}$ as legislation designed to enhance the jury's role as representative of the community, the Court stressed that "the Committee Reports of both the House and the Senate recognized that the jury plays a political function in the administration of the law." [emphasis added] ${ }^{105}$ That political function was articulated in the House Report as follows:

99. McGautha v. California, 402 U.S. 183, 199 (1971).

100. Jenkins v. Georgia, 418 U.S. 153 (1974); Hamling v. United States, 418 U.S. 87 (1974). In Hamling, Justice Rehnquist wrote for the Court that a juror may "draw on knowledge of the community or vicinage from which he comes in deciding what conclusion the average person, applying contemporary community standards' would reach in a given case." 418 U.S. at 105.

101. 419 U.S. 522 (1975).

102. Id. at 530 .

103. Id.

104. 28 U.S.C. $\$ \$ 1861$ et. seq. (1976).

105. Taylor v. Louisiana, 419 U.S. 522, 529 (1975). 
It must be remembered that the jury is designed not only to understand the case, but also to reflect the community's sense of injustice in deciding it. [emphasis added $]^{106}$

Justice White's language, that the function of the jury is to protect against arbitrary power by making available the common-sense judgment of the community "in preference to the professional . . judge," ${ }^{107}$ supports the jury nullification position. This conclusion seems especially true when this language is added to his later observation that the jury is "critical to public confidence"108 in the processes of law.

A jury that is denied the nullification instruction is less apt to act as the common-sense conscience of the community and may be apt to disrespect the system that deliberately withholds vital information necessary for its performance. ${ }^{109}$ It seems hypocritical to laud the jury as a bastion of liberty, protecting the citizens from oppression by the government, but decide that jurors should not be informed that this is their historic role. As explained above, ${ }^{110}$ early common law juries were instructed about their broad powers. Today, although the same view of the jury prevails, jurors are told far less.

$\mathrm{V}$

\section{How Jury Nullification Works in Practice Today}

Indiana and Maryland have maintained their commitments to a candid jury nullification instruction, and they provide laboratories that illustrate how this instruction operates. ${ }^{111}$ Although further empirical work is necessary, scholars and judges have written frequently about the instruction in recent years.

\section{A. Indiana}

The Indiana Constitution says that "[i]n all criminal cases whatever, the jury shall have the right to determine the law and the facts." 12 During the

106. H. R. Rep. No. 1076, 90th Cong., 2d Sess. 8 (1968); 1968 U.S. Code Cong. Ad. News 1797.

107. 419 U.S. at 530

108. Id

109. The Supreme Court has not, of course, granted the jury power to decide all questions of law, see, e.g., Jackson v. Denno, 378 U.S. 368 (1964), and has in general tried to encourage legislatures to provide general guidelines to aid juries in their exercise of discretion. See, e.g., Giaccio v. Pennsylvania, 382 U.S. 399 (1966); United States v. Park, 421 U.S. 658, 678 (1975) (Stewart, J., dissenting); and Gregg v. Georgia, 428 U.S. 153 (1976).

110. See text at footnote 23, supra.

111. Georgia's code also preserves the right of the jury to decide the law: "On the trial of all criminal cases the jury shall be the judges of the law and the facts, and shall give a general verdict of 'guilty' or 'not guilty' " . . GA. CODE ANN. \$ 27-2301 (1978). The Georgia Supreme Court has, however, interpreted this provision to deny the jurors the opportunity to learn that they have this power. Brown v. State, $40 \mathrm{Ga} .689$ (1870).

112. InD. Const. art.1, \& 19. See generally Note, The Jury's Role Under the Indiana Constitution, 52 IND. L.J. 793 (1977) [hereinafter cited as Indiana Note]. 
nineteenth and early twentieth century this provision was cited rarely, but the Indiana Supreme Court stated in 1967 that it means exactly what it says, and is constitutional: ${ }^{113}$

It appears to this Court that Art. I, $\$ 19$ taken in conjunction with the presumption of innocence is far from an outmoded, archaic anachronism. Rather, despite its venerable age, it appears to be in the vanguard of modern thinking with regard to the full protection of the rights of the criminal defendant. [emphasis added $]^{114}$

The decisions of the Indiana appellate courts explain how the jury nullification instruction works in actual practice. A review of some of the recent decisions may reduce fears that critics of the instruction have expressed.

\section{Can the Jury Declare a Statute Unconstitutional?}

No. The Indiana Supreme Court has stated, in cases involving the prostitution statutes of Indiana that, "the constitutionality of a statute is not a matter for the jury." 115 The jury's prerogative lies with questions of the application of the law. The question of the law's constitutionality resides with the courts.

\section{Can the Jury Define or Create Crimes?}

No. Although no case has been presented to Indiana's appellate courts where the jury has created a new crime on its own, the Indiana Supreme Court has specifically rejected the jury's power to do so on several occasions:

It was never intended that the legislative prerogative to define crime be extended to the jury. ${ }^{16}$

Juries are not at liberty to create new offenses, or find a defendant guilty of an offense not charged even though they might attempt to do so, because the

113. Holliday v. State, 254 Ind. 85,257 N.E. 2d 679 (1970).

114. Pritchard v. State, 248 Ind. 566, 576, 230 N.E. 2d 416, 421 (1967).

115. Sumpter v. State, 261 Ind. 471, 480,306 N.E. 2d 95, 102 (1974), cert. denied, 425 U.S. 952 (1976); Fultz v. State. 265 Ind. 626, 629, 358 N.E. 2d 123, 125 (1976); Beavers v. State, 236 Ind. 549, 558, 141 N.E. 2d $118,122(1957)$.

116. Denson v. State, 263 Ind. 315, 320, 330 N.E. 2d 734, 737 (1975). This statement was made in response to a convicted armed robber's appeal challenging the trial court's refusal to give one of his instructions. The requested instruction was taken from Article $1, \S 18$, of the Constitution of Indiana which provides that "[t]he penal code shall be founded on the principles of reformation, and not of vindictive justice." The defendant contended that the instruction should have been given because the jury is the determiner of the law and facts.

The Supreme Court found that Article 1, § 18, "is an admonition to the legislative branch of the government" in relation to the formation of public policy, and that "the jury is, in fact, confined to the existing law of the State in making a determination in a criminal case." 263 Ind. at 320,330 N.E. $2 \mathrm{~d}$ at 737 . The Court ruled that although the instruction was "a correct statement of the law, it is inapplicable as an instruction to a trial jury." 263 Ind. at 320,330 N.E. $2 \mathrm{~d}$ at 737. Thus, it seems that the jury may not define what is a crime, but must take the law as defined by the legislature and then determine its applicability in a given criminal case. The Court stated that "[i]t is [the jury's] ... duty to apply the law to the facts of the case, and they have to be the judge of both, to come to a conclusion as to both." 263 Ind. at 319,330 N.E. 2d at 737 . 
judge in the last analysis has a duty under his oath to invoke the constitution, and prevent a travesty on justice..$^{17}$

\section{Can the Jury Return a Conviction for a Lesser Offense When the Evidence}

\section{Does Not Support a Conviction for This Offense?}

This question is similar to the one the U.S. Supreme Court faced in the 1895 Sparf and Hansen case, ${ }^{118}$ and it has been discussed on several occasions by the Indiana courts. Juries are authorized to convict for lesser-included offenses that are "necessarily" included in the charged offense, if all elements of the lesser crime are included in the greater crime. Problems arise when the "lesser" offense has additional elements. The manslaughter instruction in Sparf and Hansen appeared to present this problem because manslaughter generally requires a sudden heat of passion, but that element may not be necessary for murder.

Indiana's Third District Court of Appeals considered this issue in 1976 in an assault case. ${ }^{119}$ The accused, Holloway, was stopped in his automobile by a police officer for suspicion of shoplifting. Before the police officer could arrest him, Holloway drove into the officer, knocking him down and causing bruises and minor abrasions. Holloway was charged with "assault and battery with intent to kill," but the jury returned a verdict of "aggravated assault and battery," a charge that is not necessarily a lesser-included one because a required element is great bodily harm or disfigurement.

The Court of Appeals reversed the conviction because the lesser charge was not supported by the evidence thus holding that Indiana juries cannot alter the legislative requirements for conviction even when convicting for a lesser offense. The court distinguished other cases that permit juries to convict for manslaughter even without a sudden heat of passion by concluding that the sudden heat requirement is a legal fiction that helps define manslaughter as "an intentional and unlawful killing without malice."120 Under this interpretation, manslaughter becomes a "necessarily" lesser-included offense, and jury convictions for manslaughter when murder is charged become proper. $^{121}$

This issue is likely to arise again, but the Holloway case provides sound guidance about how the jury nullification instruction relates to these difficult issues. Juries instructed on their power to nullify have no greater power to

117. Beavers v. State, 236 Ind. 549, 557-58, 141 N.E. 2d 118, 122 (1957), citing Parker v. State, 136 Ind. 284,35 N.E. 1105 (1894).

118. Sparf and Hansen v. United States, 156 U.S. 51 (1895), discussed in text at notes 36-40, supra.

119. Holloway v. State, 352 N.E. 2d 523 (Ind. App. 1976).

120. Id. at $\mathbf{5 2 6 .}$

121. Compare Sparf and Hansen v. United States, 156 U.S. 51 (1895), text at notes 36-40, supra, and holdings in other jurisdictions, note 40, supra. 
depart from the statutory guidelines defining crimes than do juries not so instructed.

\section{Can the Court Give Mandatory Instructions?}

No. The trial judge cannot tell the jurors they must convict if they find certain facts, ${ }^{122}$ but the judge can explain the law to the jurors and give them guidelines and examples about how the law was meant to be applied. ${ }^{123}$ The jurors are also told that they have the right to determine and construe the law themselves, even though their determination may differ from the judge's. ${ }^{124}$

\section{What Is the Role of Counsel?}

Indiana's courts have been silent on the role of the lawyers in discussing the law with the jury. Trial judges generally control counsel arguments, but whether a trial judge could prevent an attorney from presenting a version of the law contrary to the judge's instruction remains an unresolved issue in Indiana. ${ }^{125}$

\section{Summary}

Indiana has adjusted easily to its nullification instruction and jurors appear to have acted responsibly. There is no evidence indicating that juries are acquitting more often or that judges are unhappy with the instruction. Appellate courts are interpreting the provision conscientiously, recognizing the important role that juries play, but also protecting the rights of the accused. ${ }^{126}$

\section{B. Maryland}

Maryland's constitutional provision on the jury's power reads as follows:

In the trial of all criminal cases, the Jury shall be the Judges of Law, as well as of fact, except that the Court may pass upon the sufficiency of the evidence to sustain a conviction. ${ }^{127}$

122. Pritchard v. State, 248 Ind. 566, 230 N.E. $2 d 416$ (1967); see also Candler v. State, 266 Ind. 440, 363 N.E. $2 d 1233$ (1977).

123. Powell v. State, 160 Ind. App. 557, 312 N.E. 2d 521 (1974) provides one example. The trial judge told the jurors that "the use of the slightest force in pushing aside a door in order to enter does constitute a breaking through the doorway." Id. at 560,312 N.E. $2 \mathrm{~d}$ at 522 . The defendant asserted that this language was mandatory in character. Id. The appellate court ruled that "[a]lthough this instruction is not of a class that should serve as a model for future jury instructions due to its mandatory nature, it served only to point out to the jury the sole conclusion they could have reached given certain facts, and not to select one ultimate conclusion of fact for the jury from several alternatives." Id. at 561, 312 N.E. 2d at 523. Thus, although a mandatory instruction "invades the constitutional province of the criminal jury," $i d$. at 561,312 N.E. 2d at 523, this instruction was not grounds for reversible error because the accused was not prejudiced "since the jury could not have properly found otherwise." Id.

124. See, e.g., Sankey v. State, 157 Ind. App. 627, 634-35, 301 N.E. 2d 235, 239 (1973).

125. See generally Indiana Note, supra note 112, at 806-10.

126. Id. at $810-11$.

127. MD. Const. art. $15, \S 5$. 
Because of this constitutional mandate, this instruction is given to criminal jurors in Maryland:

Members of the Jury, this is a criminal case and under the Constitution and the laws of the State of Maryland in a criminal case the jury are the judges of the law as well as of the facts in the case. So that whatever I tell you about the law while it is intended to be helpful to you in reaching a just and proper verdict in the case, it is not binding upon you as members of the jury and you may accept or reject it. And you may apply the law as you apprehend it to be in the case. ${ }^{128}$

This instruction is different from ones suggested above as appropriate jury nullification instructions, ${ }^{129}$ but its use helps to understand how the nullification instruction might work.

\section{The Nature of the Instruction}

How does the Maryland jury instruction work in practice? Some of the answers to questions about the jury's role in Maryland are like those in Indiana. Jurors do not, for instance, have the right to declare a statute unconstitutional, and lawyers are not permitted to argue that a statute is unconstitutional. ${ }^{130}$

To protect the accused from a jury that might act improperly, a number of safeguards have been built into the trial process. The trial judge decides all questions concerning the admissibility of evidence. If either party requests the judge to do so, he or she must give the jury an advisory instruction on the law. If the trial judge thinks insufficient evidence exists to support a jury verdict of guilty, he or she is empowered to issue a directed verdict of acquittal. If the jury has misapplied the law to the prejudice of the accused, the trial judge can order a new trial. Similarly, the Maryland Supreme Court can review the sufficiency of the evidence if the defendant argues on appeal that the jury has convicted improperly. ${ }^{131}$ The defendant, therefore, has the benefit of a jury determination on the applicability of the law, but is protected from a jury that might use its power to the defendant's detriment.

The attorney is allowed to argue the law to the jury and can present any disagreement about the applicable law to the jurors for their resolution. ${ }^{132}$

128. Wyley v. Warden, 372 F.2d 742, 743 n.l (4th Cir. 1967). Jurors are sometimes cautioned against relying on their own prejudices, and can be instructed not to "apply the law as you think it ought to be or what it should be, but what, in fact, it is in this case." Hamilton v. State, 12 Md. App. 91, 98, 277 A.2d 460, 464 (1971).

129. Compare examples in the text at notes 3,9 , and 44 , and in note 64 .

130. Franklin v. State, $12 \mathrm{Md} .236$ (1858).

131. Slansky v. State, 192 Md. 94, 108, 63 A.2d 599, 606 (1949); Giles v. State, 229 Md. 370 , 384-85, 183 A.2d 359, 366 (1962), appeal dismissed for want of a substantial federal question, 372 U.S. 67 (1963). Cf. Brady v. Maryland, 373 U.S. 83 (1963) (court, not jury, rules on effect improperly excluded evidence would have had on jury's verdict).

132. Lewis v. State, 2 Md. App. 678, 686-87, 237 A.2d 73, 78 (Ct. Spec. App. 1968). 
The judge may, however, "dissent" from counsel's interpretation, and present his or her views in the form of an "advisory" instruction. ${ }^{133}$

\section{How Maryland's Trial Judges View the Instruction}

The instruction informing jurors about their power appears to have served Maryland well. One critic of the instruction, writing in 1943, conceded that in Maryland "[c]riminal trials go on with fair success and justice."134 More recently, Professor Gary J. Jacobsohn surveyed Maryland's judges in 1975 to determine their views. ${ }^{135}$ Professor Jacobsohn sent questionnaires to the eighty-one circuit court judges and received forty-four responses. The questionnaire asked what effect the instruction had on the outcomes of trials. Most responded that the instruction had "not been a significant factor in shaping the output of the trial process." ${ }^{136}$ Only three of the responding judges felt that trial outcomes were frequently affected by the instruction; another eight said verdicts were occasionally affected. ${ }^{137}$ Jacobsohn suggested that many lawyers did not take advantage of the instruction because they were uncertain about its meaning and their rights. ${ }^{138}$ Only eight of the forty-four responding judges felt negatively about the instruction. The responses of most judges suggest that they think the instruction should be retained. ${ }^{139}$ Jacobsohn surmises that "to the extent that the provision is valued, it is valued precisely because its impact is so marginal." 140

Professor Jacobsohn also asked the judges specifically about jury nullification. Twenty-two of the thirty-six judges who responded to this question disapproved of this jury power; the other fourteen supported it because such verdicts informed them about community reactions to the laws and enabled the jury to act as the "conscience of the community." ${ }^{41}$ The judges who commented on disagreements they had experienced with juries did not think many were actually instances of jury nullification. Only two judges felt that opposition to the relevant law was the most important factor in such disagreements, and only two others felt that opposition to the anticipated harshness of

133. Sizemore v. State. 5 Md. App. 507. 518-19, 248 A.2d 417. 424 (Ct. Spec. App. 1968); see Schanker v. State, $208 \mathrm{Md}$. 15. 22, 116 A.2d 363, 367 (1955); Jacobsohn. The Right to Disagree: Judges, Juries, and the Administration of Criminal Justice in Maryland, 1976 WAsH. U.L.Q. 57I. $577-79$.

134. Dennis, Maryland's Antique Constitutional Thom. 92 U. PA. L. Rev. 34. 39 (1943).

135. Jacobsohn, supra note 133.

136. Id. at 585 .

137. Id. at 584, tab. 1 .

138. Id. at 580-81, tab. 6.

139. Id. at 590 .

140. Id. at 589 .

141. Id. at 597.598 n.71. Most of the judges who opposed nullification did so because they felt it infringed on the judicial domain, rather than constituting a usurpation of legislative power, which, according to Jacobsohn, "may be the most powerful theoretical objection to the practice." Id. at 597. See note 4l. supra. 
the penalty was the crucial fact. ${ }^{142}$ Other judges explaining judge-jury disagreement mentioned the juors' reaction to the defendant's personality or to the persuasive force of one of the attorneys. ${ }^{143}$ These comments explained the infrequent instances when the jury verdict differed from the judge's view of the case.

Although forty of the forty-four responding judges stated that their own instructions constituted one source of law for the jurors, a significant number stated that jurors received knowledge of the law from other sources. Twelve judges felt that the attorneys' interpretations of law were one source of law relied on by the juries. Seven judges felt jurors relied on their own knowledge of the law and nine stated that jurors relied on their emotional commitments. ${ }^{144}$ Professor Jacobsohn summarizes this part of his study:

It appears, then, that the traditional deference to the judge's authority is not seriously, if at all, diminished by the advisory nature of judges' instructions in Maryland. Nevertheless, the fact that more than one out of every four judges believes that counsel's interpretations of the law constitute an important source of juror legal awareness calls attention to the difference between Maryland's practice and that of other jurisdictions. ${ }^{145}$

Thus, two states tell their jurors they should do more than simply evaluate the facts; and their criminal justice systems apparently work as well as those of other states. Nonetheless, most judges and some commentators continue to resist this idea. It is, therefore, important to take a closer look at the contours of the current controversy.

\section{VI}

The Current Debate Over Jury Nullification

Modern opposition to the jury nullification instruction can be divided into five arguments:

(a) it would be anarchy to give it;

(b) it is unnecessary;

(c) it is unwise;

(d) the nullification power is necessary, but better left unsaid; and

(e) the instruction would impair the responsibility of the juror.

We will consider these arguments in this order.

\section{A. The "Anti-Anarchy" Position}

Some critics of the jury nullification instruction describe it as an insidious device that beckons anarchy under the innocent guise of jury sovereignty.

142. Id. at $\mathbf{5} 86$.

143. Id. at 586,586 n.60.

144. Id. at 587 , tab. 3. The numbers add up to more than 44 because the judges were asked to give multiple responses if appropriate.

145. Id. at 581 . 
They feel that if juries were given a nullification instruction, lawlessness would result. ${ }^{146}$ One illustration of this position appeared in a 1971 editorial in the American Bar Association Journal, ${ }^{147}$ in response to a panel discussion on the role of the jury:

\section{Nihilism at Santa Barbara}

The [w]ork of institutions such as the Center for the Study of Democratic Institutions at Santa Barbara certainly deserves to be encouraged. The nation needs organizations, not connected with either local or national government, in which impartial and objective research is done on the manner in which our governments are operating. Now and then, however, proposals are made that are not only on the silly side but also dangerous to the fundamental principles on which our system of government is based.

This is illustrated by a position taken by Jon M. Van Dyke, a visiting fellow at the center, in a discussion on "The Jury as a Political Institution." According to the center's magazine of July, 1970, Professor Van Dyke urged that jurors be given full authority to disregard the instructions of the judge as to what the law is, stating: "We should tell the jurors that they have the power to acquit, even if the accused's activities have violated the law as it is articulated by the trial judge."

Certainly no principle of law could survive if a jury were free to disregard it, substituting only the jury's own sense, which might be rational or emotional, of what fairness and justice require. As a participant in the same panel at which Professor Van Dyke made his proposal, Abe Fortas, the former [U.S.] Supreme Court Justice, put his finger on the vice of the proposal by pointing out:

In effect, it is an attack upon law itself. In effect, it is an assertion of the right of the individual to determine for himself what the standard of his conduct shall be. What is being proposed is not merely that jurors should be given the power to determine what is the law, but that they should be instructed that they may acquit a defendant even though they believe that he did something the law forbids. This goes to the heart of our society because it says that this shall not be a society in which there are general rules of law and conduct which apply to everybody and to which everybody is held accountable.

Another participant, Judge Simon H. Rifkind, put the finishing touch to the argument:

Mr. Van Dyke asks why, if I am in favor of some kind of departures by the jury, I am afraid to make that universal. The answer is that one can have a fine musical composition made up of a theme with variations, but if you had a composition made up entirely of variations you would have discord. His proposal would create law-less society, not a lawless society, but a law-less society, a society without law, without regulations. That is a monstrosity. No such society has ever existed or ever will exist.

The "anti-anarchy" argument has also been urged by some judges ${ }^{148}$ and has

146. See, e.g., United States v. Dougherty, 473 F.2d 1113, 1134 (D.C. Cir. 1972).

147. 57 A.B.A.J. 999 (1971).

148. A particularly good illustration of the anti-anarchy school and the emotional rather than 
been adopted by some courts, most notably by the U.S. Court of Appeals for the Fourth Circuit ${ }^{149}$ and by the Kansas Supreme Court which said that "[d]isregard for the principles of established law creates anarchy and destroys the very protections which the law affords." 150

Advocates of the "anti-anarchy" position over-dramatize what jury nullification means. Supporters of the nullification instruction agree that the jury should be instructed to take its interpretation of the law from the judge. But nullification proponents contend that the dispensing power of the jury, which all concede to exist, may properly be exercised in certain cases in the interest of justice and that the jury has the right to be so instructed. The dispensing power is not the power to make law, is not the power to redefine the law, is not the power to supplant the law with the jury's own notions of what it should be, is not the power to overrule the law, and certainly is not the power to take the law into the jury's own hands. ${ }^{151}$ The dispensing power is a power of conscience which permits the jury to suspend the application of a particular law in a particular instance to a particular defendant in the interest of conscience and justice.

Police officers investigating criminal matters have discretion whether or not to make an arrest. Prosecutors have discretion whether or not to bring criminal charges to court. Trial judges have discretion whether or not to allow the case to proceed to trial. Jurors, who also act on behalf of the public, have discretion in deciding whether or not to convict the accused. Frequently, however, jurors are not informed that they have this discretion, thus depriving the accused of an important safeguard. ${ }^{152}$

In many situations warranting mercy, the police officer, prosecutor or judge will act to temper the rigor of the law to let an individual remain free despite a technical violation of the law. In some instances-when the glare of

\footnotetext{
logical nature of its presentation is McBride, The Jury Is Not A Political Institution, 11 JUdGe's Journal 37 (April 1972). Judge McBride describes what he understands jury nullification to be as "an unworkable and essentially irresponsible theory" that is "born of anarchy and destructive of democracy and any other form of government with justice under law." Id. at 38.

149. United States v. Moylan, 417 F.2d 1002 (4th Cir. 1969), cert. denied, 397 U.S. 910 (1970). See also United States v. Wiley, 503 F.2d 106 (8th Cir. 1974).

150. State v. McClanahan, 212 Kan. 208, 216, 510 P.2d 153, 159 (1973), discussed at notes 46-48 supra.

151. Note how these questions are clarified in Indiana and Maryland, discussed in text at notes $111-45$, supra.

152. After the 1968 Boston trial of Dr. Benjamin Spock, Rev. William Sloane Coffin and three others for aiding draft resisters (see 416 F.2d 165 (1st Cir. 1969)), several jurors reported that they felt they had no choice but to return a guilty verdict after the trial judge's narrow instructions. One juror noted: "I knew they were guilty when we were charged by the judge. I did not know prior to that time-I was in full agreement with the defendants until we were charged by the judge. That was the kiss of death!" J. Mitrord, The Trial of Dr. Spock 232 (1969). Not everyone inpaneled as a juror remembers the lessons of their American history courses when they learned about John Peter Zenger.
} 
publicity limits discretion or when the government has a particular stake in the prosecution because of the nature of the accusation-only the jury has the freedom to act mercifully. We value the jury because it can introduce common sense and conscience when the law and governmental officials may not be in touch with those values. Judge Learned Hand explained this phenomenon a generation ago, with his elegant phrasing:

... The institution of trial by jury-especially in criminal cases-has its hold upon public favor chiefly for two reasons. The individual can forfeit his liberty - to say nothing of his life-only at the hands of those who, unlike any official, are in no wise accountable, directly or indirectly, for what they do, and who at once separate and melt anonymously in the community from which they came. Moreover, since if they acquit their verdict is final, no one is likely to suffer of whose conduct they do not morally disapprove; and this introduces a slack into the enforcement of law, tempering its rigor by the mollifying influence of current ethical conventions. A trial by any jury, however small, preserves both these fundamental elements and a trial by a judge preserves neither, at least to anything like the same degree. [emphasis added] ${ }^{153}$

Jury nullification, rather than destroying the law, is necessary to protect it. As Roscoe Pound pointed out long ago, the law on the books is often quite different from the law in practice. ${ }^{154}$ "Jury lawlessness," he said, "is the great corrective of law in its actual administration." 155 When the law becomes too rigid, too mechanical, or too far behind public opinion, the jury may make minor adjustments to bring it back into conformity with justice. In this way, according to Pound, the letter of the law may be kept, yet the jury may be allowed to accommodate it to the law in practice. Pound appears to approve of this power, although he correctly points out that a legal system that relies too heavily upon the jury as a corrective device is far from the optimal system. Jury nullification is paradoxical in this respect. The more juries exercise their power to acquit, the more they illustrate the defects in the legal system that need correcting by more equitable legislation or prosecutorial practices. ${ }^{156}$ In James Gould Cozzens's novel, The Just and Unjust, a jury returns a merciful verdict that contradicts the evidence. The assistant district attorney, son of the small town's wise old judge, now retired, tells his father that the jury has acted outrageously. The old judge patiently explains to his distressed son:

.. Justice is an inexact science. As a matter of fact, a judge is so greatly in a jury's debt, he shouldn't begrudge them the little things they help themselves to.

... .

153. United States ex rel. McCann v. Adams, 126 F.2d 774, 775-76 (2d Cir. 1942).

154. Pound, Law in Books and Law in Action, 44 Am. L. Rev. 12 (1910).

155. Id. at 18 .

156. This explanation of Roscoe Pound's thinking should meet the statements of Judge Leventhal in United States $v$. Dougherty who read Pound in a different way, see 473 F.2d 1113. 1134-35 (D.C. Cir. 1972). 
... The jury protects the Court. It's a question how long any system of courts could last in a free country if judges found the verdicts. It doesn't matter how wise and experienced the judges may be. Resentment would build up every time the findings didn't go with current notions or prejudices. Pretty soon half the community would want to lynch the judge. There's no focal point with a jury; the jury is the public itself. That's why a jury can say when a judge couldn't, 'I don't care what the law is, that isn't right and I won't do it.'. . . They may be wrong, they may refuse to do the things they ought to do; but freedom just to be wise and good isn't any freedom. We pay a price for lay participation in the law; but it's a necessary expense. ${ }^{157}$

Advocates of the "anti-anarchy" school fail to evaluate fully the extent to which the dispensing function of the jury shores up respect for the law. ${ }^{158}$ Those who disapprove of this important function are in the uncomfortable position of arguing that the jury should have convicted John Peter Zenger, should have sent scores of persons to the gallows in seditious libel cases, should have returned guilty verdicts for prosecutions under the British Navigation Act, the Embargo Act, the Fugitive Slave Law, and should have convicted more regularly in countless capital punishment cases in the days when 230 or more offenses carried that penalty in England. Should these juries have simply examined the facts and fit them to the law enunciated by the judge? Or should they have used their conscience and common sense to acquit? Have these instances of "anarchy" destroyed the legal system?

157. J. Cozzens, The Just and Unjust 427-28 (1942).

158. Wigmore discussed this phenomenon with the following language:

Law and Justice are from time to time inevitably in conflict. That is because law is a gencral rule (even the stated exceptions to the rules are general exceptions); while justice is the fairness of this precise case under all its circumstances. And as a rule of law only takes account of broadly typical conditions, and is aimed at average results, law and justice every so of ten do not coincide. Everybody knows this, and can supply instances. But the trouble is that Law cannot concede it. Law-the rule-must be enforced-the exact terms of the rule, justice or no justice. 'All Persons are Equal before the Law; this solemn injunction, in large letters is painted on the wall over the judge's bench in every Italian court. So that the judge must apply the law as he finds it alike for all. And not even the general exceptions that the law itself may concede will enable the judge to get down to the justice of the particular case, in extreme instances. The whole basis of our general confidence in the judge rests on our experience that we can rely on him for the law as it is. But, this being so, the repeated instances of hardship and injustice that are bound to occur in the judge's rulings will in the long run injure that same public confidence in justice, and bring odium on the law. We want justice, and we think we are going to get it through 'the law' and when we do not, we blame the law. Now this is where the jury comes in. The jury, in the privacy of its retirement, adjusts the general rule of the law to the justice of the particular case. Thus the odium of inflexible rules of the law is avoided, and popular satisfaction is preserved ... . That is what jury trial does. It supplies that flexibility of legal rules which is essential to justice and popular contentment. And that flexibility could never be given by judge trial. The judge (as in a chancery case) must write out his opinion declaring the law and the findings of fact. He cannot in this public record deviate one jot from those requirements. The jury, and the secrecy of the jury room, are the indispensable elements in popular justice. [emphasis added]

Wigmore. A Program for the Trial of a Jury, 12 AM. JuD. Soc. 166 (1929). 
The "anti-anarchy" argument, with its emotional appeal and intellectual confusion, is not the strongest argument against a jury nullification instruction. Some commentators have offered a more informed and intelligent discussion of the issue, to which we now turn.

\section{B. The "Nullification-is-Unnecessary" Position}

Some critics of jury nullification argue that a nullification instruction is unnecessary because it does not serve any useful function in our legal system. The evils that jury nullification is designed to correct, it is argued, are better handled through other legal channels. Professor Gary J. Simson has expressed his criticism more strongly than others. ${ }^{159}$ In his view, jury nullification can be valuable in only two distinct situations: first, where an unjust law is involved; and, second, where a judge makes an unjust interpretation of a just law. ${ }^{160}$ Professor Simson concludes that a jury nullification instruction is unnecessary because both situations can be resolved properly within the confines of the existing rules. Unjust laws can be declared unconstitutional or can be legislatively changed; the judge's construction of a statute can be challenged on appeal.

Jury nullification proponents would not restrict the need for nullification to these two situations. A partial list of situations when the exercise of conscience by the jury is particularly important to protect the defendant and to ensure the fairness of the legal system would include the following:

(1) the prosecutor may be overzealous in bringing a prosecution because a particularly prominent or controversial person is involved or because of some personal relationship between the prosecutor and one of the parties;

(2) the trial judge may not be able to view the case objectively because of personal eccentricity or deep-seated bias;

(3) the government may be the victim of the crime in a way that makes it impossible for the prosecutor not to prosecute or for the judge to dismiss the matter;

(4) the case may be so highly publicized that prosecution is unavoidable even though undesirable;

(5) the government may have, in the opinion of the community, overstepped legitimate bounds in its efforts to bring the defendant to trial; and

(6) the defendant may be a highly sympathetic person who (the community feels) has suffered enough, has been singled out unfairly for prosecution, has violated an unpopular law, or has acted in a manner which the community does not condemn.

159. Simson, supra note 41.

160. Id. at 508 . 
In many of these cases, the jury is the only institution sufficiently free of technical legal constraints to reach a just and reasoned conclusion.

Candor and honesty require us to inform the jurors that we expect them to respond to these situations when they arise. As explained in Section IV above, ${ }^{161}$ we expect our jurors to "make" law in many instances. If we refuse to tell jurors they have the power to act conscientiously in appropriate circumstances, we may be unnecessarily constraining their actions when we clearly want them to help establish legal norms. It seems better to frame a clear and concise nullification instruction than to rely on the happenstance that a strong juror may remember from a high school history course that jurors sometimes rejected the court's view of the law.

\section{The "Nullification-Is-Unwise" Position}

Jury nullification has been criticized on the ground that it is inconsistent with democracy because it allows a single juror to overthrow the majority will as expressed in legislative enactments. This "anti-democratic" character of jury nullification has persuaded some commentators to disapprove a nullification instruction.

Professor Simson, for example, has argued that a nullification instruction would be more detrimental than beneficial because "juries told of their right to nullify would often frustrate the people's sense of justice by refusing to enforce an act of Congress, for in all probability Congress' decision rather than the jury's will reflect the majority's view." ${ }^{62}$ Of course, an occasional jury will refuse to apply a law in its attempt to do justice, as some juries did last century with the Fugitive Slave Act. It is unlikely that this will happen often, however, because most laws do have the support of most people, or they would not be laws. If a law is frequently nullified, it probably is not reflective of the people's will and the jurors, as representatives of the people, are saying so.

Juries are more likely to exercise their nullification power, however, in a case involving a factual setting the legislature did not anticipate. Legislation is not so specific that it responds to every situation. ${ }^{163}$ Even assuming that legislation reflects the wishes of the majority, the majority may not have understood the full implications of its law. If legislators considered the extenuating circumstances of the case at bar, they might not desire strict application of the statute. The jury performs the important function of occasionally resisting majority will when minority rights need protection. In the rare instances when

161. See text at notes 66-110, supra.

162. Simson, supra note 41 , at 512 .

163. See Aristotle, Ethics, Book V, ch. 10, fol. 1137, and 2 Plowden 459, 466, 467, quoted in L. Hand, The Bill of Rights 20-22 (1958) and in P. Brest, Processes of Constitutional. DecisionmaKing 34-35 (1975). 
the jury suspends the law, it is more apt to be supporting national policy than otherwise. The history of nullification certainly supports this interpretation.

The "nullification-is-unwise" argument does not seem to be directed primarily at nullification. It seems rather to be directed at the jury system in general, and, more particularly, the requirement that jury verdicts be unanimous. But whatever the target, this argument fails to appreciate the unique role of juries. A central feature of the jury system, and the entire judicial system in many cases, is the fact that it should not be answerable to the popular will. The jury exists to protect minority rights and to prevent a majority from imposing its will on the powerless. It may also help prevent a majority from violating its own rules in the heat of passion, prejudice or retribution. Justice Joseph Story saw this point clearly:

The great object of a trial by jury in criminal cases is, to guard against a spirit of oppression and tyranny on the part of rulers, and against a spirit of violence and vindictiveness on the part of the people. Indeed, it is often more important to guard against the latter than the former $\ldots{ }^{164}$

The executive and legislative branches of the government are designed to answer to the majority. Without protection of minority interests by the judiciary, our government would have infringed on the rights of minorities frequently. In some cases, nullification is an essential response to majority overreaching. By failing to recognize that the jury, as part of the judiciary, is entrusted with sacred responsibilities in guarding minority rights, many legal scholars seek to use its "anti-democratic character" as an argument against its right to nullify. In fact, it is an argument in favor of it. ${ }^{165}$

An honest and candid jury nullification instruction has an important psychological dimension that offers clear political benefits. Professor Simson reluctantly concedes that although he thinks nullification does "more harm than good," he would nevertheless not tinker with the jury's present power to nullify because he fears "that any measures calculated to diminish significantly

164. 2 J. Story, Commentarifs on the Constitution of the United States $\$ 1780$ (5th ed. 1891).

165. A related conflict of views occurred in the case of Johnson v. Louisiana, 406 U.S. 356 (1972), in which the Court ruled that a unanimous jury vote was not necessary for conviction and that a 9-3 jury vote was constitutionally acceptable. Justice Powell argued in his concurring opinion that the possibility of "juror irrationality" justified a less-than-unanimous vote. Id. at 377. Justice Marshall attacked this approach in his dissent from a perspective that is consistent with the historical protections that have been provided by our jury system. Justice Marshall argued that what Justice Powell called "irrational" is

precisely the essence of the right of a jury trial ... . The juror whose dissenting voice is unheard may be a spokesman, not for any minority viewpoint, but simply for himself-and that, in my view, is enough. The doubts of a single juror are in my view evidence that the government has failed to carry its burden of proving guilt beyond a reasonable doubt.

Id. at 402-03. See generally, J. VAN Dyke, Jury Selection, supra note 2, at 203-14. 
the scope of the jury's current power to nullify [would cause] unacceptable repercussions for the system as a whole." ${ }^{166}$ We agree that it would have that effect, but so does failure to inform the jury of their right to nullify.

In a democracy, the people are sovereign. The jury, as representative of the people, constitutes democratic self-rule. ${ }^{167}$ Denying the dispensing power to jurors creates the appearance of impotence. Jurors who are not informed of their powers, but are told instead that they do not have those powers and must obey the judge's instructions, will learn a lesson in democracy: that they do not rule themselves. The refusal to give a nullification instruction is an attempt to reduce popular sovereignty and replace it by the rule of experts. ${ }^{168}$

Professor Simson has raised a series of other objections to a nullification instruction which lead him to the conclusion that the instruction is politically unwise. For example, in his opinion, if juries are instructed that they can nullify bad laws, those laws are more apt to stay on the books than if juries convicted. ${ }^{169}$ Professor Simson appears to believe that it is better that more people suffer so that they may convince their legislators (from their jail cells) to change the laws. This approach seems awkward and unrealistic. ${ }^{170}$ The inability to convict under a bad law serves to remove that law from the books at least as convincingly as does sending people to jail under it, and fewer people suffer unjust punishment.

Professor Simson has also argued that jury nullification will produce more biased verdicts, will encourage convictions, and will not produce just decisions. He says that an "invitation to jurors to vote their consciences is inevitably an invitation to greater parochialism in jury decision-making. Local biases . . are legitimated and activated. ..."171 Even further, he says that activation of these

166. Simson, supra note 41, at 524. Professor Simson is particularly concerned about weakening "the integrity of the reasonable doubt standard." Id.

167. See Scheflin, supra note 8 , at $188-90$, for a discussion of the jury and participatory democracy.

168. See also Kershen, supra note 67 , at 88 n.450.

169. Simson. supra note 41, at 514-15.

170. In our view, legal injustice should be resisted whenever it is faced and not ignored in the hope that someone else will do the right thing. Professor Simson overlooks two important points. First, if juries continue to nullify, the law cannot be applied successfully and further use of it would arouse public indignation. Second, the history of the nullification power disproves the argument that jury acquittals keep bad laws on the books. Quite the reverse is true. See the text at notes 79-80, supra.

171. Simson, supra note 41 , at 514 . Judge Bazelon responds to this argument by reminding us that "[t]he very essence of the jury's function is its role as spokesman for the community conscience in determining whether or not blame can be imposed." United States v. Dougherty, 473 F.2d 1113, 1142 (D.C. Cir. 1972) (Bazelon, C.J., dissenting). The exercise by the jury of its nullification power, whether one agrees with that particular acquittal or not, is an important indicator of the relationship between the community and its laws. No doubt the jury will occasionally acquit on the basis of considerations other than justice. The proper response is not to take away the jury power to acquit, but instead to educate the public to reduce the role of bias and prejudice. So "the solution is not to condemn the nullification power, but to spotlight the prejudice and paro- 
local biases "may at times in effect immunize criminal acts visited upon members of society's 'discrete and insular minorities,' " a consequence which he says "is not one that I at least can take lightly." "72 We share Professor Simson's concern that the invitation to do justice will invite unwelcome guests. A jury that is instructed to suspend the law only on the basis of conscience and justice may well act, in fact, from ignorance and prejudice. If the jury represents a cross section of the community, the prejudices of individual jurors should cancel each other out to produce a collective sense of justice and fair play, but this may not always happen. ${ }^{173}$

Proponents of jury nullification have never doubted that jury acquittals

chial values that underlie the verdict in the hope that public outcry will force a re-examination of those values, and deter their implementation in subsequent cases." Id. at 1143. This solution is an honest one that seeks to confront the source of acquittals rather than the fact of them.

172. Simson, supra note 41 , at 514 .

173. When a jury returns a verdict of acquittal, or a verdict more lenient than the evidence suggests is permissible, there is a natural tendency to assume that the jury has nullified. But this may not always be the proper explanation.

The May 1979 jury verdict in the case of Dan White might at first be viewed as an instance of a jury altering the law in a way that did not produce justice. White was accused of murdering San Francisco Mayor George Moscone and Supervisor Harvey Milk, a leader of San Francisco's large gay community. The jury returned a verdict of "voluntary manslaughter" instead of "murder" which was the original charge. This verdict astounded many observers because White had sneaked into the City Hall with a loaded gun, killed Moscone in cold blood, reloaded his gun, and then killed Milk in a nearby office. Significant rioting and destruction occurred in San Francisco after the lenient verdict was returned. Media reaction was antagonistic towards the jury verdict.

In our view, this verdict was not a case of jury nullification, but rather a case of an inept prosecution and a non-representative jury. The prosecution, for reasons which remain obscure, did not present a very strong case. White's personal background was largely ignored and the political controversy which provided a strong motivation for the killings was strangely excluded from the prosecution's presentation of evidence. Moreover, the jury that was assembled was not representative of San Francisco's heterogeneous community. Because the original charge carried the possibility of a death penalty, all jurors with doubts about the death penalty were excluded from the panel. No gay persons were selected to serve as jurors. No blacks served on the jury panel and no Asians were selected.

What was particularly unusual was not merely the non-representative nature of the jury, but rather the fact that the prosecutor helped to make it so by challenging potential jurors whose backgrounds suggested they might have been more favorable to the prosecution. In short, both the defense lawyers and the prosecutor chose the same portion of the San Francisco community to bump from jury service. The jury thus chosen was predictably defense-prone from the start.

The Dan White case contains a further complication. The prosecution did not call on experts to testify concerning White's state of mind at the time of the killings. Since the actual facts were not in doubt, a mental defense was the only available argument left to the defense. Although the prosecutor did introduce psychiatric testimony in rebuttal, it was a half-hearted effort which fell before a persistent and carefully constructed cross-examination. The lack of a challenge to the extensive mental excuse testimony supplied by defense psychiatrists left the jury with only one strong side of the case to consider-the side of mercy.

The lenient verdict in the Dan White case was not the product of jury nullification, it was the product of a deficient prosecution and an unrepresentative jury which did not really serve as the conscience of the community.

See the excellent analysis in W. Hinckle, Dan White's San Francisco, Inquiry, Vol. 2, No. 18, at 8 (October 29, 1979). 
will, in some rare cases, be more deplorable than beneficial to the community. But even these jury acts are not entirely without their useful purpose. As Judge Bazelon pointed out in his Dougherty dissent:

One oft-cited abuse of the nullification power is the acquittal by bigoted juries of whites who commit crimes (lynching, for example) against blacks. That repellent practice cannot be directly arrested without jeopardizing important constitutional protections-the double jeopardy bar and the jury's power of nullification. But the revulsion and sense of shame fostered by that practice fueled the civil rights movement, which in turn made possible the enactment of major civil rights legislation. That same movement spurred on the revitalization of the equal protection clause and, in particular, the recognition of the right to be tried before a jury selected without bias. The lessons we learned from these abuses helped to create a climate in which such abuses could not so easily thrive. ${ }^{174}$

Professor Simson says that even though jury nullification may bring the "system closer to the people's sense of justice," ${ }^{175}$ proponents have never proved that in doing so our legal system actually becomes more just. In Simson's language: "The proponents of jury nullification assume that it does, and this assumption forms the foundation for the nullification position." 176 Professor Simson's attack is misguided. Nullification proponents do not rest their argument on the ground that the people's sense of justice is the most just. If they did, they might argue that juries also have the right to convict even when the evidence has not proved guilt beyond a reasonable doubt. Nullification rests more on political than on moral grounds. ${ }^{177}$ Proponents believe that people have the right to govern themselves within the boundaries of the Constitution. The Constitution sets the rules for American democracy; protections such as the right to due process, and protections against double jeopardy and ex post facto laws, are vital to sustain the uniqueness and individual freedoms of us all. Nullification is not a doctrine that seeks to replace the restraints of law. Those restraints are vital for people living together in societies. But those restraints could become repressive and defeat the goals of political and social

174. 473 F.2d 1113, 1143 (D.C. Cir. 1972) (Bazelon, C.J., dissenting). The frequently-offered example of the Southern jury acquitting the white who lynches a black is also misleading because those Southern juries did not contain a cross section of their community. Juries that were representative probably would not acquit in such circumstances. See Van Dyke, 16 CATH. Law. supra note 8 , at 238 .

175. Simson, supra note 41 , at 511 .

176. $I d$.

177. Nullification proponents also defend the doctrine on moral grounds but it is its political significance which is most important. Because nullification supports popular sovereignty and protects against governmental tyranny, majority oppression, and legal injustice, it is to be defended primarily on political grounds. Although the decision to nullify is usually a moral decision, it may not always be so. Nullification proponents admit that juries occasionally act immorally in the exercise of their dispensing power. But nullification is a political process that protects even the freedom to reach an immoral conclusion. The price, we believe, for elimination of this occasional immoral result is elimination of political freedom. That price is too high to pay. 
freedom they were devised to protect. Nullification responds to the right of the people to be unjust if they so choose, provided they obey the ground rules of the Constitution in the process. If freedom means anything, it means one is free to make mistakes and upon occasion to do the wrong thing. But it is also the freedom to correct one's mistakes and to avoid repeating them. If occasional injustice is the price we must pay to be free, we do not feel that it is an excessive cost. Bringing the law closer to the people may not make it more just in all cases, but it will make it the law of the people, which is what it should be in a constitutional democracy.

A final criticism of jury nullification by Professor Simson concerns the possibility of increasing jury convictions. Simson says that "[a] jury free to decide where blame should justly lie may acquit a defendant guilty under a faithful application of the law, but it may also convict a legally innocent defendant."178 As explained earlier, ${ }^{179}$ jury nullification proponents have maintained strenuously that the jury instruction must clearly indicate that although the jury may acquit on the basis of conscience, it may not convict unless convinced beyond a reasonable doubt that the defendant violated the law. In an earlier article, one of us criticized a draft of a nullification instruction drawn up by the Kansas trial judges because the instruction failed to make this point clear. ${ }^{180}$ The instruction was revised in light of this criticism. ${ }^{181}$ Professor Simson knows that proponents argue that nullification is a conscience technique, but he is not convinced. He says "any court persuaded to recognize a right to nullify would probably find the proposal unacceptable, because it draws a wholly unprincipled distinction." 182

Professor Simson may think that the difference between vengeance and mercy is an "unprincipled distinction" but many legal thinkers have felt that

178. Simson, supra note 41 , at 516 . He also says:

... By authorizing the jury to place blame where it sees fit, jury nullification, even when made formally acquittal-oriented, enhances the likelihood that defendants will be convicted of conduct that they are not on notice to avoid. The jury in effect passes a new statute and proceeds to convict the defendant for its violation. Indeed, jury nullification invites convictions under statutes not simply vaguely known to defendants but not known to them at all ....

Id. at 520. Professor Simson provides no evidence to support his claim that convictions will increase. He fails to mention that even if juries should improperly convict, their verdict can be overturned. He asserts that the nullification instruction asks jurors "to place blame where [they] see fit." Id. A nullification instruction does not ask a jury to place blame where it chooses; it explains that the jurors have the power to recognize that certain technical violations of law may be blameless.

179. See text at notes 15-16, supra, and see Section $V$ on the Indiana and Maryland experiences, text at notes 111-45, supra.

180. Scheflin, supra note 8, at 205-07.

181. Personal communications from Judge Frederick Woleslagel, Division 1, Twentieth Judicial District, Kansas, to Alan Scheflin on Jan. 20, 1972 and Jan. 27, 1972. Judge Woleslagel was the principal draftsman of the Kansas nullification instruction.

182. Simson, supra note 41 , at 516 . 
this is a distinction essential to our freedoms. ${ }^{183}$ In the first place, this "unprincipled distinction" is deeply imbedded in our law already. Juries can acquit in cases where the state cannot appeal, but jury convictions may be subjected to a wide variety of challenges at the trial and appellate levels. Second, jury nullification proponents do not say, as Professor Simson asserts they do, that "a jury is better suited than a legislature to place blame." ${ }^{84}$ Simson says that the nullification position replaces the legislature with the jury, and therefore, the jury should have the authority "to mete out greater penalties than required by law as well as lesser ones." ${ }^{185}$ He says that the nullification instruction "makes sense only if the goal of the criminal justice system is maximizing acquittals rather than improving the quality of criminal justice."186

Proponents of jury nullification do not view the matter in this light, but rather see the nullification instruction as an added protection for a defendant in criminal cases. The law of criminal procedure is designed to protect the defendant against governmental overreaching. The exclusionary rule, the requirement of proof beyond a reasonable doubt, the presumption of innocence, the ability of a defendant to challenge and appeal jury convictions, the prohibition against double jeopardy, and countless other rules protect the defendant and ensure fairness. No one argues seriously that the purpose of these rules is to "maximize" acquittals, and this is not the purpose of the jury nullification instruction. Professor Simson's balancing off of "acquittals" with "improving the quality of criminal justice"187 seems inappropriate. Would we improve the quality of criminal justice by allowing police to return to "the third degree"? We would get more convictions. Is that the type of improvement Simson is talking about? Elimination of the third degree improved criminal justice by forcing police to obtain hard evidence of guilt. It eliminated laziness, for, as Sir James Stephen wryly noted, "it is far pleasanter to sit

183. If there is such overwhelming evidence of guilt that no rational jury could find that the defendant was not guilty and a jury nevertheless returns a verdict of not guilty, does it follow that the jury has acted irrationally? Should we then avert our eyes from that all too plain verdict, pretending that the jury has acted inscrutably?

We could be done with such pretenses if we abandoned the unrealistic supposition that the jury is invariably limited to deciding questions of fact. In the narrow area of criminal acquittals, it may do more; it may also evaluate the law and veto its application in the case before it.

In contrast with the tacit veto of a law, a verdict of guilty adjudges the merits not of the law but of the facts. Whatever leeway a jury has sub silentio to narrow the application of a law by an acquittal or by convicting the defendant of a lesser offense, it has no comparable leeway to enlarge the application of the law by a verdict of guilty. Hence an appellate court can evaluate a verdict of guilty in terms of whether there has been harmless error or harm by reference to what a rational jury might do. [emphasis added]

R. Traynor, The Riddle of Harmless Error 30-33 (1971). Chief Justice Traynor obviously does not see the difference between acquittals and convictions as "a wholly unprincipled distinction."

184. Simson, supra note 41 , at 516 .

185. Id.

186. Id.

187. Id. 
comfortably in the shade rubbing red pepper into a poor devil's eyes than to go about in the sun hunting up evidence." 188 The price for this improvement may have been fewer convictions, but the improvement in the criminal justice system (in ensuring that only the guilty are convicted) is apparent and highly beneficial. A jury nullification instruction provides similar benefits.

Professor Simson further suggests that not only judges but juries also may not understand the difference between acquittals and convictions. He fears that if the jury is "[i]nstructed that it is fine to ignore the command of the law to do justice in some instances, then, juries are apt to feel unconstrained by law from doing what they believe to be just in all instances." ${ }^{89}$ Careful instructions by the judge and the reviewability of convictions should eliminate this difficulty, if indeed it is one. ${ }^{190}$ An instruction clearly and candidly stating that the jury may acquit on the basis of conscience, but may not so convict is more likely, we believe, to be obeyed than no instruction at all. This point will be amplified in the next Section. For now, we restate our belief that jurors are able to see the difference between acquittal and conviction, are not so callous that they would lightly disobey the judge's instructions, and are not so foolish that they would jeopardize their liberties and consciences by unduly claiming unlawful authority.

Two other arguments have been made recently against the nullification instruction. The current debate centers around them. In the next two Sections, we focus on these objections that have been carefully articulated by distinguished scholars and judges.

\section{The "Damn-Good-Reason" Position}

Professors Mortimer and Sanford Kadish have written the most complete version of this argument in Discretion to Disobey. ${ }^{191}$ They accept the naked power of the jury to nullify, but question whether the jury has the right to do so (and be so instructed). Kadish and Kadish offer two models of the jury's function. The first requires that the jury always follow the judge's instructions and never exercise the power of nullification; the second allows the jury to do whatever it thinks best in all cases. Both models follow the "rule-of-law model for official roles;" 192 each by its terms disallows room for a notion of rule departures. Both models are rejected by Kadish and Kadish for neither is an accurate description of how the jury functions. Jurors are told to follow the law,

188. I J. Stephen, $A$ History of the Criminal Law 441, quoted in Pound, Law in Books and Law in Action, 44 Aм. L. Rev. 12, 17 (1910).

189. Simson, supra note 41 , at 516 .

190. See, for instance, the Indiana experience described in the text at notes 116-21, supra.

191. Kadish \& Kadish, Discretion to Disobey (1973) [hereinafter cited as Kadish \& KADISH].

192. Id. at 59 . 
but they are at liberty not to do so. This flexibility gives the juror a "recourse role"193 that Kadish and Kadish describe as the authority to reexamine the constraints (such as following the judge's instructions on the law) when those constraints appear to conflict with the goals they were set up to further (such as justice). This recourse role, the dispensing power of the jury, thus serves a valuable purpose in the legal system.

The recourse role differs from expressly delegated discretion, according to Kadish and Kadish, in that the jury (acting in its recourse role) is not told explicitly to exercise its best judgment in the case. ${ }^{194}$ Nor is the recourse role a "usurpation," because it is not exercised by the jury in defiance of their authority. ${ }^{195}$ Rather, the jury occupies a position of "legitimated interposition"196 which permits it to move legitimately beyond its normal constraints and depart from the rules that ordinarily govern its conduct.

Kadish and Kadish approve of the jury's recourse role, but emphasize that a difference exists between a juror's rejection of the judge's instructions "at will" and a juror's departure from them "because he has 'damn good reason'." 197 The line between "at will" and for a "damn good reason" is not always a clear one, of course. In order for a reason to be "damn good," according to Kadish and Kadish, it must be consistent with the goals of the legal system. In other words, the juror may depart legitimately from the otherwise obligatory instructions of the judge only if this departure is absolutely essential "as determined by the role ends he is committed to serve . . ."198 These ends include justice because " $t]$ he rules of law have presumably been formulated to achieve justice. The jury liberty is extended because in some unknown and hence unstable circumstances" the rules of law may not achieve justice, "and the determination of those circumstances is left at large to the jury." 199

Nevertheless, the question of how justice is to be served in any given case is not free from ambiguity. Is every jury departure a "legitimate" one under this theory? Kadish and Kadish argue that this is not the case. They argue that any decision to depart that is not based on serving the ends of the legal system is not a proper exercise of the juror's recourse role. An example

193. Id.

194. Id. at 66 .

195. Id.

196. Id. When a legal system presents an official with the liberty to depart from a rule that might work against his achieving the ends of his role, it legitimates his departure from the rule; that is, it legitimates the interposition between the rule and his action of Id. at 67.

his own judgment that departure from the rule best serves the prescribed end.

197. Id. at 62 . "But we claim only that the jury is at liberty to depart from the judge's instructions, not that it has a right to do so at will." Id. at 60 .

198. Id. at 62 .

199. Id. at 63 . 
would be the bribed juror. ${ }^{200}$ What if the jury departure was intended to serve the interests of justice, but the juror's perception of justice differs substantially from that of the rest of the society? Kadish and Kadish discuss the example of acquittal by a white southern jury of white defendants accused (and clearly guilty) of murdering blacks and civil rights workers: ${ }^{201}$

... Is this an instance of legitimated rule departure? The answer, we think, has to be yes. One is entitled to say that this jury is egregiously wrong in its interpretation of the ends of its role . . . ; that its ventured justification rests on premises that contravene the basic ethos of the Constitution and the legal system founded on it; even that it has violated the law insofar as one may regard policies and ends of this kind as part of the law, as we do. But if our argument is correct, one cannot say that this jury has acted lawlessly, in the sense of usurping an authority it did not have ...202

Although the jury may occasionally "act in crass and damaging ignorance," 203 this is the price of liberty and "the law has chosen to take that chance in the case of the jury."204

So far, little disagreement can be found in the position of Kadish and Kadish and the position of jury nullification proponents. The two sides part company on the question whether jurors should be told about their nullification power. Kadish and Kadish argue that they should not be told. Despite Kadish and Kadish's recognition of the value of the nullification power and their assertion that "the jury's fundamental function is not only to guard against official departures from the rules of law, but on proper occasions themselves to depart from unjust rules or their unjust applications," ${ }^{205}$ they nevertheless object to informing the jury of this power for two reasons.

First, by not informing the jury of its nullification power, the legal system can ensure that such power will only be exercised when there is a "damn good reason" for it. By instructing the jury that they must follow the law, an "extra surcharge"206 is imposed on their departure. This helps to limit jury nullification only to those instances of great injustice where the jury is especially prepared, on the basis of conscience, to override the judge's instructions.

The second objection raised by Kadish and Kadish to giving a nullification instruction follows from the first. If the instruction were given, it would increase the number of times that juries nullified. It would be an invitation to wide-scale disobedience. ${ }^{207}$ Thus, the refusal to instruct the jury on the nullifi-

200. Id. at 68 .

201. Id.; see also note 174 , supra.

202. KaDISH \& KaDish, supra note 191, al 68.

203. Id. at 69 .

204. Id.

205. Id. at $53-54$.

206. Id. at 65 .

207. Id. Professor George Christie, a jury nullification opponent, nevertheless finds the 
cation power serves for Kadish and Kadish the dual advantages of ensuring that the power will be used only in extraordinary cases of injustice and of limiting the number of times the power is exercised at all. Kadish and Kadish prefer the present balance-the jury may, and should, nullify in certain cases but it need not be told about this power.

Judicial support for this view is found in the majority opinion of the Dougherty case ${ }^{208}$ where Judge Leventhal, drawing upon an earlier version of the Kadish and Kadish argument, ${ }^{209}$ adopted it fully. According to Judge Leventhal,

[T] he existence of an unreviewable and unreversible power in the jury, to acquit in disregard of the instructions of the law given by the trial judge, has for many years[s] co-existed with legal practice and precedent upholding instructions to the jury that they are required to follow the instructions of the court on all matters of law. ${ }^{210}$

Judge Leventhal accepts the present balance of power between judge and jury. To instruct the jury of the nullification authority would, he fears, encourage them to act as a mini-legislature 211 "determining the rules of law." 212 This result, when coupled with the unanimity requirement, would expose the "criminal law and administration to paralysis, and to a deadlock that betrays rather than furthers the assumptions of viable democracy." 213 Judge Leventhal believes that failure to inform the jury of its nullification authority will not prevent the jury from exercising its power in exceptional cases because the jury informs itself about its role in other ways than through the judge's instructions. ${ }^{214}$ For example, he cites the media, literature, conversations with others, and history as sources of informal knowledge of jury function and responsibility. These sources "convey adequately enough the idea of

Kadish and Kadish position to be inconsistent in its refusal to permit the jury to be instructed as to its power to nullify:

... It seems to me that if the legal system really does recognize justified rule departures by juries, then a defendant is entitled to have the jury instructed on that subject. Otherwise, his fate depends upon whether the jury chosen to hear his case happens to be sufficiently cantankerous or tough-minded or imaginative to disregard what the judge tells them and look instead to the deeper structure of the legal system. I do not see how anything so chancy can be called legitimate; the stakes are too high to resort to a lottery.

Christie, Lawful Departure from Legal Rules: "Jury Nullification" and Legitimated Disobedience, 62 Calif. L. Rev. 1289, 1303 (1974) [hereinafter cited as Christie].

208. United States v. Dougherty, 473 F.2d 1113 (D.C. Cir. 1972), discussed in the text at notes 49-58, supra.

209. Kadish \& Kadish, On Justified Rule Departures by Officials, 59 CALIF. L. Rev. 905 (1971)

210. United States v. Dougherty, 473 F.2d 1113, 1132 (D.C. Cir. 1972).

211. Id. at 1136 .

212. Id.

213. Id. Note how the arguments concerning the nullification instruction relate to the arguments concerning jury unanimity; see note 165 , supra.

214. "The jury knows well enough that its prerogative is not limited to the choices articulated in the formal instructions of the court." Id. at 1135 . 
prerogative, of freedom in an occasional case to depart from what the judge says." 215 One asks whether this reliance on informal information conveyance is not dishonest and irresponsible, like relegating sex instruction of one's children to the streets rather than assuming parental responsibility to do the job. Judge Leventhal replies that when the legal system leaves the responsibility of informing the jury of its dispensing power to informal channels "it is not being duplicitous, [nor is it] chargeable with chicane and intent to deceive."116 Rather, it is "a governor to avoid excess."217

For Judge Leventhal, the informal processes of information maintain the necessary tension between law and justice. Tampering with that delicate structure (by telling jurors they have the power to nullify) would distort the balance by eliminating the constraints now provided by the judge's instructions. Anticipating the nullification proponents' objection that it is irrational to favor jury power while disfavoring discussion of it, Judge Leventhal, in a telling piece of candor, concludes:

In the last analysis, our rejection of the request for jury nullification doctrine is a recognition that there are times when logic is not the only or even best guide to sound conduct of government. ${ }^{218}$

Nullification proponents would respond that a government that can exist only by formally and officially deceiving its citizens may not be worth preserving in the first place. In addition, Judge Leventhal's view seems unfair to defendants whose jurors may not have learned informally of their nullification power or may have been convinced that it is a relic of the past after hearing the judge's limiting instruction.

The contours of the current controversy over jury nullification flow from the Kadish and Kadish-Leventhal views. Except for occasional backsliding, the "anti-anarchy" language has disappeared from discussions, to be replaced by more intelligent concern about the proper exercise of the jury's special dispensing power. The line that separates adherents and opponents of jury nullification is whether or not to instruct the jury of their nullification authority. Kadish and Kadish, Judge Leventhal in the Dougherty case, the U.S. Court of Appeals for the Ninth Circuit, ${ }^{219}$ and others have rejected the instruction in favor of the present balance of power. Their arguments, presented above, are well reasoned but, as we shall try to demonstrate, ultimately unpersuasive.

219. United States v. Simpson, 460 F.2d 515 (9th Cir. 1972). The court concluded that "the existing safeguards are adequate" so that the instruction, which might encourage acquittals, should not be given. Id. at 519-20. 


\section{Will the Acquittal Rate Increase if the Nullification Instruction is Given?}

The essential premise of the "damn-good-reason" position, that juries will act in a different and less desirable way if informed about their nullification power, is not based on actual occurrences ${ }^{20}$ and is not convincing in theory. Why do nullification opponents feel that the more knowledgeable jurors become, the less conscientiously they will act? ${ }^{221}$ Why do nullification opponents assume that juries will run amuck after being told by the judges that they should exercise their nullification powers only after careful and conscientious deliberation and only on the basis of conscience or justice? Is this innate distrust of juries a product of traditional professional elitism that has sought to eliminate the lay and uninitiated from a share in the law ${ }^{222}$

Proponents of nullification prefer to demystify the law by making it accessible and responsible to the community it serves. An honest instruction would give the jurors a sense of responsibility, respect, and influence over the law that regulates their lives. Proponents do not fear the power of juries to nullify and do not expect good and honest citizens to turn suddenly into lawless anarchists on the basis of a judicial instruction to deliberate with conscience and justice. The ordinary jury deliberating about a violent crime is unlikely to ignore the law and the judge's instructions, because the people are victims of these crimes. Consider, for example, the following comments of a black juror about jury duty:

Some defense lawyers may feel that the predominately middle-aged, predominately black jury most often chosen in the District [of Columbia] is more sympathetic to the black defendant. But they are espousing what seemed to me yet another bit of folklore. In fact, quite the opposite is true. Enough crime is enough, such juries feel. We are the victims. You see it on the unsigned exit questionnaires handed out at month's end in the early-sunset wintertime. "Give us more protection walking from the Courthouse to the bus." Or "This is a high crime neighborhood; don't hold us in the court past dark." 223

This view is supported by the Chicago Jury Project's monumental study of the jury system. When attempting to explain examples of disagreement between judge and jury, Professors Harry Kalven and Hans Zeisel wrote:

220. See the discussion of the Indiana and Maryland experiences text, supra notes 11 1-45.

221. United States v. Dougherty, 473 F.2d 1113, 1136-37 (D.C. Cir. 1972).

222. On the tension in early American law between professionals and the laity, see P. Miller, The Life of THE Mind in America 99-116 (1965). For the view that judges perceive jurors and laypersons as unsophisticated, see Note, Jury Nullification: The Forgotten Right, 7 NEw ENG. L. REv. 105 (1971). The author suggests that jury nullification is not only guaranteed by the sixth amendment but also by the ninth which protects rights of the people not enumerated in the Constitution. Because jury nullification was a common-law right at the time of the drafting of the Constitution, according to this view, it has been retained by the people under the ninth amendment. Id. at 121 .

223. Spingarn, Eye the Jury, The Washington Post, Sept. 10, 1972, \& Potomac, at 16. 
[W]e suspect there is little or no intrinsic directionality in the jury's response. It is not fundamentally defendant-prone, rather it is non-rule minded; it will move where the equities are. And where the equities are at any given time will depend on both the state of the law and the climate of public opinion. [emphasis added $]^{224}$

Other commentators support the proposition that juries act sensibly even if they are given a nullification instruction. A recent Yale Law Journal survey ${ }^{25}$ of social-psychology literature on this question addressed Judge Leventhal's fear of unjust acquittals and "a loss of the tension in the juror's role between following general law as opposed to the juror's own sense of justice."226 The survey also examined Chief Judge Bazelon's dissent in that case, which argued that sufficient internal checks, balances, and constraints exist to prevent juries from acquitting excessively. In Judge Bazelon's view, jurors are not apt to free dangerous persons to return and prey on the community from which those jurors are drawn. ${ }^{227}$ Is the position of Judge Leventhal or Judge Bazelon more accurate? The Yale survey concludes:

... Social psychological research indicates that the internal checks referred to by Chief Judge Bazelon are very real and that, even where he knows of his power of nullification, a juror has a strong psychological need to see the case settled according to his sense of equity. ${ }^{28}$ This need should act as a restraint on the juror's feelings of sympathy for the defendant. In light of a judge's probable influence as an authority figure on the way jurors perceive their own roles, an instruction which informed the jury of its power of nullification but at the same time conveyed the legal system's expectation that it follow the general law in reaching its verdict would likely retain the necessary tension in the jury's role. ${ }^{229}$

224. H. Kalven \& H. Zeisel, supra note 10, at 495; see also Myers, Rule Departures and Making Law: Juries and their Verdicts, 13 L. \& SOC. REv. 781 (1979).

225. Note, Toward Principles of Jury Equity, 83 YALE L.J. 1023 (1974).

226. Id. at 1051 .

227. United States v. Dougherty, 473 F.2d 1113, 1143 (D.C. Cir. 1972) (Bazelon, C.J., dissenting).

228. It should be mentioned here that "equity" is not being used as a synonym for "justice." Indeed, the two concepts might at times be antagonistic to each other. The jurors' sense of treating the defendant equitably might very well conflict with the sense of treating the defendant justly. For example, the equitable imperative to treat all persons alike might cause tension with the desire to treat this particular defendant as an exception in order to do justice.

229. Note, Toward Principles of Jury Equity, supra note 225, at 1051-52.

The Solicitor General of the United States has written that jury nullification is not likely to produce biased, discriminatory or anarchic verdicts. Responding to the argument that the death penalty is unconstitutional because jury discretion can result in capricious and arbitrary verdicts, the Solicitor General agrees with Judge Bazelon that jurors may be trusted to act responsibly:

The potential vice of jury nullification, even though its availability is created by the Constitution, in that the jury may acquit in an irrational or prejudicial manner. However, the constitutional guarantee of a jury trial rests on the assumption that the jury is not animated by bias, and that the jury is capable responsibly of discharging its duties. If the jury is given to caprice, it would undermine convictions for any crime no less than convictions for capital crimes. But this Court has always assumed that, at least when screened from prejudicial pressures and from legally inadmissible but "powerfully 
Another example supporting the good judgment of jurors who are given the right to nullify can be offered from the British experience following the passage of Fox's Libel Law in 1792. That statute authorized juries to pass on the law as well as the facts, ${ }^{230}$ but passage did not make it more difficult for the Crown's prosecutors to obtain criminal convictions. ${ }^{231}$

We feel that logic, common sense, and the available evidence support the conclusion that a carefully drafted instruction informing the jury of its nullification power would not produce unjust acquittals or increase the likelihood of departures from the law except in rare situations justifying departures. The burden now falls on nullification opponents to demonstrate that their fears are justified. ${ }^{232}$ But even if our view of the empirical evidence is mistaken and even if the level of acquittals would rise, we feel nonetheless that other considerations support giving the nullification instruction.

\section{Honesty Is the Best Policy}

The arguments for opposing the nullification instruction are, in our view, deficient because they fail to weigh the political advantages gained by not lying to the jury. ${ }^{233}$ Even if Kadish and Kadish and Judge Leventhal are correct about the resultant decrease in tension in the juror's role, this element must be balanced against the fact that this tension is maintained by deceit. What

incriminating extrajudicial statements" (Bruton v. United States, 391 U.S. 123, 135), the jury can be trusted to decide the controversy reasonably, conscientiously, and intelligently. See McGautha, supra [402 U.S. 183 (1971)]. Cf. Duncan v. Louisiana, supra, 391 U.S. at 157 .

The argument that juries will act unfairly and arbitrarily assumes that, on this most serious decision, twelve jurors who have been carefully screened by defense counsel will silently cast their votes for private reasons without reference to the commands of the law. The available evidence is to the contrary. Professors Harry Kalven, Jr. and Hans Zeisel, in preparing their massive study The American Jury (1966), analyzed in depth the workings of more than 3,500 jury trials, and concluded that in the great majority of cases in which the jury declined to convict (whether or not of a capital offense) when the evidence apparently was persuasive, the jury was making a reasoned and reasonable response to the excessiveness of a penalty in light of the nature of the crime and the circumstances of the defendant. The authors uncovered no evidence that the jury was bchaving capriciously in these instances of "nullification" (id. at 306-312).

We submit that there is simply no evidence that the jury, when deciding whether to convict in capital cases, acts in a wanton or freakish or discriminatory manner. The jury is fulfilling a function given to it by the Constitution itself; more is needed than petitioners' groundless speculation that the jury might act irrationally to demonstrate that the Constitution's guarantee of trial by jury is a bar to the imposition of capital punishment.

Brief for the United States as Amicus Curiae in Gregg v. Georgia, at 90-91. 428 U.S. 153 (1976).

The Attorney General of North Carolina has echoed similar sentiments. Brief For the Respondent State of North Carolina in Woodson v. North Carolina, at 51-52. 428 U.S. 280 (1975).

230. See the discussion of this statute, text at note 27 , supra.

231. See Sax, supra note 8, at 491-92.

232. Judge Bazelon has also extended this challenge to nullification opponents. United States v. Dougherty, 473 F.2d 1113, 1141 (D.C. Cir. 1972) (Bazelon, C.J., dissenting).

233. See text at notes 167-68, supra. 
impact will this deception have on jurors who felt coerced into their verdict by the judge's instructions and who learn, after trial, that they could have voted their consciences and acquitted? Such a juror is less apt to respect the legal system. As Judge Bazelon has cogently observed, the trial judge is not neutral on nullification because it is a doctrine "that must not only be concealed from the jury, but also effectively condemned in the jury's presence."234 Therefore, even if a few more seemingly irrational acquittals were to result from the nullification instruction, which we doubt, the price would be worth the benefit to democracy, honesty and each individual's pride in governmental participation.

\section{Internal Inconsistency}

Another objection to the view of those who argue against giving the nullification instruction is that their position is internally inconsistent. Judge Leventhal favors jury nullification that spontaneously occurs because of strong juror feelings or that results from knowledge of jury power obtained outside the courtroom. He rejects explicitly instructing jurors about the power he admits they have. He appears to want jurors to know what they can do, but he does not want to be the one to tell them. This position creates a serious dilemma because of its inconsistency. What ruling would Judge Leventhal make on the question whether a prosecutor could challenge every potential juror for cause who has heard about jury nullification? In the 1970-71 New York City Black Panther trial, the judge permitted the prosecutor to ask prospective jurors. "Do you have any reservations in your mind that if Robin Hood were indicted for robbery, that you would convict him of robbery even though he might have wanted to give money to the poor?"235 If Judge Leventhal agrees that all persons with knowledge of the nullification power can be removed from the jury, he would defeat his purpose of having the jury know about its powers without being specifically instructed. On the other hand, if he refuses to allow the prosecutor to ask questions about nullification, because jurors are entitled to sit on juries knowing about nullification, would he permit the defense to inform them of their power? If not, then jurors with distorted, prejudiced or misinformed views of their role would sit in judgment of their peers.

According to Judge Leventhal's reasoning, as Judge Bazelon's dissent

234. United States v. Dougherty, 473 F.2d 1113, 1140 (D.C. Cir. 1972) (Bazelon, C.J., dissenting). See also Note, Laws That Are Made To Be Broken: Adjusting For Anticipated Noncompliance, 75 Mich. L. Rev. 687 (1977):

... , the nullification rule relies essentially on deception-that is it operates by means of deception. The nullification rule leads at least some jurors to believe that they do not have the ability to nullify and arguably deceives at least some jurors into believing that the legal system regards all instances of nullification as undesirable. Moreover, this deception is not innocuous: it has an adverse impact on jurors. [footnotes omitted] Id. at 712 .

235. E. Kennebeck, Juror Number Four 36 (1973). 
points out, ${ }^{236}$ the legal system has no duty to be honest with jurors. Indeed, its duty is to be affirmatively dishonest by instructing jurors that they must obey the judge's instructions and by preventing counsel from arguing to the contrary. This view harms the people the nullification doctrine exists to protect. If Judge Leventhal's view remains the law, only those persons with enough education or knowledge of legal proceedings, or with friends who are lawyers, will know what authority they possess when they sit on juries. The more complacent, obedient, less educated, and less intelligent members of society will not have this knowledge and the legal system will not inform them of it. Against such a discriminatory practice, we prefer, with Judge Bazelon, to dissent.

\section{The Nullification Instruction Would Produce More Rational Verdicts}

Nullification opponents feel that unjust verdicts would increase if the jury is informed of its authority to acquit despite a technical violation of the law. But is not the reverse more likely? Judge Bazelon notes:

... The juror motivated by prejudice seems to me more likely to make spon-
taneous use of the power to nullify, and more likely to disregard the judge's
exposition of the normally controlling legal standards. The conscientious ju-
ror, who could make a careful effort to consider the blame-worthiness of the
defendant's action in light of prevaling community values, is the one most
likely to obey the judge's admonition that the jury enforce strict principles of
law. ${ }^{237}$

The nullification instruction, therefore, would serve to discourage acquittals based on prejudice instead of encouraging them, as nullification opponents argue. Because the nullification instruction sets justice and conscience as the standards for acquittal rather than leaving the jurors to use their own biases as standards, it would help prevent unjust acquittals on the basis of prejudice. The obstreperous juror who insists that juries have the power to acquit for any reason at all (a doctrine that this juror may have picked up through one of the informal channels discussed by Judge Leventhal) ${ }^{\mathbf{2 3 8}}$ would find it difficult to promote that view with co-jurors who had received a careful nullification instruction.

Defense lawyers occasionally ask the trial judge to give the so-called "Perry Mason" instruction to the jury, that at the end of the trial no person is likely to jump up and confess guilt. It was discovered that juries would sometimes convict defendants only because nobody else had confessed in the courtroom. Jurors had received their knowledge of the law and of legal proceedings in

236. United States v. Dougherty, 473 F.2d 1113, 1141 (D.C. Cir. 1972) (Bazelon, C.J., dissenting).

237. Id.

238. Id. at 1135; discussed in text at footnotes 53 and 215 , supra. 
the informal way that Judge Leventhal applauds. The legal system has incorporated a new instruction to correct this error. Judge Leventhal's position, that bad verdicts will be the consequence of the nullification instruction, seems to us to be mistaken. It is the failure to give an honest and forthright nullification instruction that may lead to injustice.

\section{E. The "Responsibility-of-the-Juror" Position}

A final objection to giving the jury nullification instruction has been raised by Professor George Christie and Judge Leventhal. Christie believes that the nullification instruction would "erode" the sense of responsibility of each juror:

... The power that juries have to ignore the judge's instructions is the price we pay, and I think should pay, to insulate the jury as much as we can from official pressure. It is like academic freedom. Instructors are free to teach nonsense. Is this because it is legitimate to teach nonsense? Of course not. It is the price we pay to free teachers from the control of authority. If an instructor "seeking truth" is in fact propagating nonsense, is he acting illegitimately? Again the answer is, not necessarily. The legal and moral universes are not always two-valued. ${ }^{239}$

The law permits nullification, but it neither authorizes nor commands it. Christie fears that the nullification instruction would be perceived by jurors as a command that they must acquit "if [they] feel strongly enough about the matter." 240 This is the basis of his objection because he believes "that the jurors alone bear responsibility for acquitting in these circumstances, not the law which permits them to get away with doing so." ${ }^{241}$ Judge Leventhal has also voiced concern about juror responsibility:
... It is one thing for a juror to know that the law condemns, but he has a factual power of lenity. To tell him expressly of a nullification prerogative, however, is to inform him, in effect, that it is he who fashions the rule that condemns. That is an overwhelming responsibility, an extreme burden for the jurors' psyche. And it is not inappropriate to add that a juror called upon for an involuntary public service is entitled to the protection, when he takes ac- tion that he knows is right, but also knows is unpopular, either in the commu- nity at large or in his own particular grouping, that he can fairly put it to friends and neighbors that he was merely following the instructions of the court. ${ }^{242}$

Professor Christie would not give the jury a nullification instruction because he believes that it would decrease the individual juror's responsibility for acquittals and would detract from the moral neutrality of the law. Judge Leventhal, on the other hand, would not give the nullification instruction be-

239. Christic, supra note 207 , at 1303 .

240. Id. at 1304 .

241. Id.

242. United States v. Dougherty, 473 F.2d 1113, 1136 (D.C. Cir. 1972). 
cause, in his view, the law must bear the responsibility for jury verdicts and the instruction would increase the individual juror's responsibility by communicating that each juror is the author of the "rule that condemns." Both Christie and Leventhal thus focus on the jurors' responsibility for their verdicts.

Let us examine that responsibility. It is not the responsibility of jurors to make laws and it is an illegitimate exercise of their authority to create new crimes. The juror does not "fashion the rule that condemns" because the jury takes the law from the court and cannot substitute its own version of what the law should be. Judge Leventhal probably has a different meaning in mind when he expresses concern about juror responsibility. He appears to be worried that if jurors are told of the nullification power, they will be under a heavy burden because they know they have the power to free the defendant. They may feel that if they convict, it is their decision and not a legal decision. We sympathize with this point of view that seeks to protect jurors, but we are compelled to disagree with it. Jury service is a heavy responsibility and any attempt to make it lighter by passing responsibility to another governmental agency or institution violates the concept of the jury. Jury service should be understood and treated as one of the most solemn and meaningful obligations a citizen can be called upon to perform. In the words of one Juror's Handbook:

Jury service is one of the most vital functions of citizenship. It is the most important duty of a citizen of the United States, next to fighting in the defense of one's country. ${ }^{243}$

The criminal juror's function is to sit in judgment of an accused person. Our system of justice is not served by trying to lighten the juror's responsibility by encouraging the juror to rely on "the law" rather than weighing the matter in terms of the community conscience. Although the juror must listen responsibly to the judge's instruction on the law, the juror cannot avoid making an individual evaluation of the defendant's conduct. Even under Judge Leventhal's view, it is permissible for jurors to know that they may nullify; many jurors do know they have this power. These jurors cannot escape responsibility in the way Judge Leventhal suggests. It seems more honest and honorable to tell all jurors about their power and responsibility in a clear and careful manner, at the same time that the judge outlines the law that governs the case.

Judge Leventhal says that jurors who have reached what they believe to be the right verdict, but who think that the community disagrees with their conclusion, can use the law as an excuse. We do not believe that it is conducive to good citizenship or good character to shift the responsibility elsewhere rather than standing up for what you believe is right. If jurors have reached unpop-

243. Jurors' Handbook, Santa Clara County, California, quoted in M. Timothy, Jury Woman 4 (1974) [hereinafter cited as M. TıмотнY]. 
ular verdicts which they feel are nevertheless correct, and if they feel that they have the obligation to explain those verdicts, then their explanation should be based upon their recognition of their own role in attempting to do justice within the law. The juror's position is a responsible one and the full impact of that responsibility must be brought home to jurors so that they may perform their historic function.

Christie objects to the nullification instruction because it would be viewed by the jury as a command by the law that they acquit "if they feel strongly enough about the matter." ${ }^{244}$ A carefully drafted nullification instruction that clearly limited situations justifying the exercise of that power ${ }^{245}$ would answer this objection. Christie's concern that jurors would feel compelled to acquit would be satisfied with an instruction stating they do not have to acquit. The instruction could explain their power to acquit, but would make clear that nullification was not commanded.

Christie, however, may have had a slightly different point in mind. He appears concerned about the law remaining value-neutral. Unlike Judge Leventhal who appears to prefer that the law absorb responsibility for jury verdicts, Christie believes that the law should be free of such responsibility. Jury verdicts, he believes, should belong to juries and the law should keep a discrete distance from them. This approach ignores the role of jury service in self-governance. As explained above, ${ }^{246}$ our law is a dynamic force that springs from the people and is ultimately accountable to them. The essence of the jury is its obligation to pass judgment on each law it is asked to apply. Laws that are found to be inequitable when applied in certain instances should be "nullified" by the refusal of the jury to convict under them. Further, the neutrality that Christie favors is jeopardized by refusal to grant the nullification instruction; for what better way is there for the law to coerce a particular verdict than by refusing to tell the jury all the options it has available? The only way to maintain the neutrality of the law and to have the jurors bear responsibility for their decisions is to inform them of their prerogatives.

Christie's comparison of the juror with the school teacher and academic freedom questions ${ }^{247}$ illustrates the problem with his approach. Professors in environments where academic freedom is nurtured are not instructed that they can only teach what they are told to teach. They do not need to rely on television and other informal sources to learn that they may teach what they want without being punished for it. They are encouraged to innovate and explore the uncertain realms of their subjects, and are usually promoted if they succeed in these endeavors. We would not have "free" teachers unless they

244. Christie, supra note 207 , at 1304.

245. See text at notes 3,9 , and 44 , and note 64 , supra, for examples.

246. See text at notes 167-68 and at notes 233-34, supra.

247. Christie, supra note 207, at 1303, quoted in text at note 239, supra. 
clearly understood that they were free to teach what they believed to be true. Similarly, we will not have "free" (and truly responsible) jurors until they are told that they have the authority to acquit on the basis of conscience in appropriate cases.

\section{VII}

\section{Conclusion and Summary}

We have shown that jury nullification is more than just a price the legal system pays for jury service. Rather, it is a distinct and unique benefit to our system of government that not only brings the community and the law closer together, but also adds a new dimension to the concept of democratic self-rule for all participating in the jury experience. Therefore, it is not merely a practice that should be tolerated, but it is a practice that should be applauded and treated with dignity and honesty. Even in those rare instances when juries reach verdicts that do not win public support, the community is learning vital lessons about itself. And, of course, whenever the jury returns a verdict with which the community morally agrees, even though it may run counter to the instructions of the judge on the law, faith in the jury system is openly vindicated.

In the final analysis, we believe that the jury power to acquit, in consideration of but against the judge's instructions on the law, is not an accidental by-product of the general verdict, the double jeopardy provision, and the judge's inability to punish jurors for their verdict. The jury, with its power of nullification, is a deliberate attempt to increase citizen participation in government, ameliorate the rigors of laws that may be too harsh when applied in certain cases, prevent governmental tyranny, bring the law and the community in closer harmony, and allow the people to make the final decision on moral blameworthiness in criminal cases. To achieve these goals, the jury must be instructed of its authority to acquit in appropriate circumstances.

Any examination of the history and development of the jury reveals how closely intertwined this institution is to the exercise of political freedom and individual liberty. ${ }^{248}$ Defense of the jury need not rest solely with the major

248. For more than seven out of the eight centuries during which the judges of the common law have administered justice in ... [England], trial by jury ensured that Englishmen got the sort of justice they liked and not the sort of justice that the government of the lawyers or any body of experts thought was good for them.

P. Devlin, supra note 66 , at $159-60$.

.. The fundamental safeguards have been established, not so much by lawyers as by the common people of England, by the unknown juryman who in 1367 said he would rather die in prison than give a verdict against his conscience, by Richard Chambers who in 1629 declared that never till death would he acknowledge the sentence of the Star Chamber, by Edmund Bushell and his eleven fellow-jurors who in 1670 went to prison rather than find the quakers guilty, by the jurors who acquitted the printer of the Letters of Junius, and by a host of others. These are the men who have bequeathed to us the heritage of freedom.

A. Denning, Freedom Under Law 63-64 (1949) [hereinafter cited as A. Denning]. 
political issues of any given era. It is in the little cases as well that the jury ameliorates the harshness of the law, thereby furthering respect for laws and legal procedures. If our legal system did not permit the dispensing function of the jury, it would grow cold and stale, the object of ridicule and disobedience. No legislature can anticipate all the situations that would fall under the terms of a statute. It is virtually impossible to write a general law to cover the identified problem, which is also detailed enough to prevent prosecution in all cases the legislature does not intend to cover. The generality of law necessitates the exercise of discretion and conscience in its enforcement.

The prosecutor has discretion to refuse indictment in sympathetic cases. In many instances, prosecutorial discretion is exercised in accord with community opinion, thus eliminating the necessity for jury nullification. But not in all cases. Prosecutors may bring defendants to trial for a variety of reasons, not all of which serve the interest of justice. Political cases attest to the willingness of prosecutors to curtail dissent by using the law as a sword to cut a wide swath through minority opposition to governmental policies. The extensive publicity given to some cases, the elective status of many prosecutors and the necessity for maintaining solid and cordial relations with the police may induce prosecutors to try cases that might otherwise not be brought to trial. In such cases, prosecutorial discretion fails to serve as a shield against unjust indictments. Jury nullification is necessary and essential to justice in these situations.

Judges also have discretion in the enforcement of laws, but they too are subject to the strictures of their role and are accountable to the people (if elected), the appellate courts, and the legal profession for their actions. In cases where justice might demand dismissal, politics may demand otherwise. Mary Timothy, jury foreperson in the Angela Davis murder case, subsequently wrote:

Suppose he [Judge Arnason] were to rule that the prosecution had not proven its case and then dismissed all charges. Then the whole thing would be over! Wouldn't that be fantastic? The decision would be made and we jurors wouldn't have that burden. Fantastic, but not likely. Could any judge take that responsibility himself in a trial with so many political overtones? I doubted it. ${ }^{249}$

Once again, the exercise of its dispensing power makes the jury indispensable to justice. The essential difference between the jury and other legal institutions is that the jury, which meets for a trial and then melts back into the

[F]or a time in eighteenth-century England a jury's uncontrolled general verdict of acquittal-given in defiance of the judge's instructions-was the strongest safeguard available for the free discussion of public affairs.

Henderson, The Background of the Seventh Amendment, 80 Harv. L. REv. 289, 328 (1966).

249. М. ТІмотну, supra note 243 , at 185 . 
community, is, in the words of Justice Douglas, "the one governmental agency that has no ambition." ${ }^{250}$ It is free to do what is right.

The right of the jury to nullify applications of law in a particular case can also be supported on political grounds as an essential aspect of democratic self-government. It serves to remind governments and legal professionals that the people are sovereign. It serves to remind the community that protection of its liberty and freedom rests in the hands of the people. The Senate and House reports on the 1968 federal Jury Selection and Service Act expressly state that, "It must be remembered that the jury is designed not only to understand the case, but also to reflect the community's sense of justice in deciding it." [emphasis added $]^{251}$

Today, the jury system is under attack. In some courts, it is shrinking in size, ${ }^{252}$ in strength, ${ }^{253}$ and in usage, ${ }^{254}$ and it is frequently criticized on grounds of expense and inefficiency. ${ }^{255}$ Part of the campaign to weaken the

250. W.O. Douglas, We, The Judges 389 (1956), quoted in A.F. Ginger, supra note 8, at 10. Douglas also says "Since [the jury] is of and from the community, it gives the law an acceptance which verdicts of judges cannot do." Id.

251. Senate Comm. on the Judiciary, Improved Judicial Machinery for the Selection of Federal Juries, S. Rep. No. 891, 90th Cong., Ist Sess. 24 (1967); House Comm. on the JudiCiary, Federal Jury Selection Act, H.R. Rep. No. 1076, 90th Cong., 2d Sess. 8 (1968).

252. In Williams v. Florida, 399 U.S. 78 (1970), the Court held seven-to-one that the number "12" for a jury was an "historical accident" and is not constitutionally required in non-capital state criminal trials. In Colgrove v. Battin. 413 U.S. 149 (1973), a divided Court held five-to-four that the seventh amendment did not require a 12-person jury in federal civil trials. For an analysis of these cases and the issue of jury size, see J. VAN Dyke, Jury Selection, supra note 2, at 193-203. In Ballew v. Georgia, 435 U.S. 223 (1978), the Court held that juries in state criminal trials could not consist of fewer than six persons.

253. In Johnson v. Louisiana, 406 U.S. 356 (1972), a divided Court held five-to-four that the fourteenth amendment's due process clause requiring proof beyond a reasonable doubt in criminal cases was not violated by a state law permitting non-unanimous jury verdicts in state non-capital criminal cases. In Apodaca v. Oregon, 406 U.S. 404 (1972), a divided Court (four-to one-to-four) held that it was not a violation of the sixth amendment for a state to permit a non-unanimous verdict in a non-capital criminal case. Justice Powell's vote joined the plurality opinion on state trials, but noted that the sixth amendment might bar non-unanimous jury verdicts in federal criminal proceedings. For an analysis of these cases and the issue of nonunanimous jury verdicts, see J. Van Dyke. Jury Selection, supra note 2, at 203-14. In Burch v. Louisiana, 441 U.S. 130 (1979), the Court ruled that if state criminal juries consist of only six persons, their verdict must be unanimous.

254. The Supreme Court has ruled in a series of cases that defendants have no constitutional right to a jury trial if they are accused of only a "petty offense." Whether or not a petty offense is involved depends upon the sentence. So far the Court has ruled that violations leading to six months in jail, three-years probation, and a fine of $\$ 10,000$ are each "petty offenses" in contempt cases. Muniz v. Hoffman, 422 U.S. 454 (1975); Taylor v. Hayes, 418 U.S. 488 (1974); Codispoti v. Pennsylvania, 418 U.S. 506 (1974); Baldwin v. New York, 399 U.S. 66 (1970); Frank v. United States, 395 U.S. 147 (1969); Bloom v. Illinois, 391 U.S. 194 (1968).

255. It is important to mention that although the Supreme Court in the last decade has weakened the constitutional protection of the jury's structure, it has not deviated from its conception of the jury's function enunciated in Duncan v. Louisiana, 391 U.S. 145 (1968), quoted in the text at note 93. Indeed, the Court has been careful to point out that it would not change the structure of the jury if it thought that the function would thereby be weakened. We are, therefore, optimistic that the Court will recognize that the nullification instruction promotes the jury's function and must therefore be supported. Kadish and Kadish, who disagree with us that the jury should re- 
jury is based on the proposition that the jury's only function is to decide the facts and that juries do a poor job at that. ${ }^{256}$

We believe that refusal to instruct the jury of its nullification power contributes to weakening the jury as a legal and political institution. It produces mendacious judges and more complacent and servile jurors (and citizens). Charles C. Curtis once remarked:

In the judge we have our intellectual side. In the jury, we have the intuitive part of us. Together they reflect each of us as the jury reflects all of us. And a society which does not trust itself may be a state, but is not a society at all. ${ }^{257}$

In dismissing the jury in the Angela Davis trial after their verdict of not guilty, Judge Arnason read to them from G. K. Chesterton:

Our civilization has decided, and very justly decided, that determining the guilt or innocence of men is a thing too important to be trusted to trained men. If it wishes for light upon that awful matter, it asks men who know no more law than I know, but who can feel the things I felt in the jury box. When it wants a library catalogued or the solar system discovered, or any trifle of that kind, it uses its specialists. But when it wishes anything done that is really serious, it collects twelve of the ordinary men standing about. The same thing was done, if I remember, by the founder of Christianity. ${ }^{258}$

The jury is responsible for the exercise of delicate moral, legal, social and political judgments. Sometimes it makes mistakes, ${ }^{259}$ but mistakes cannot be eliminated because justice cannot be programmed into a computer. Sometimes juries reach verdicts that are not popular with particular segments of the community, but a jury verdict is never without an important social lesson that will help the community. Juries are less likely to make mistakes as to their function and are more likely to benefit the community if they are honestly in-

ceive a nullification instruction, nevertheless agree that the Supreme Court has recognized "the jury's power to displace law by appeal to conscience as one of the characteristics that makes the right to a jury trial 'fundamental to our system of justice'. [Duncan v. Louisiana, 391 U.S. 145, $153(1968)]$. . . In other words, the jury's fundamental function is not only to guard against official departures from the rules of law, but on proper occasions themselves to depart from unjust rules or their unjust application." KaDISH \& KADISH, supra note 191, at 53-54. The only real issue concerning jury nullification is whether or not the jury should be honestly instructed as to its authority. The value of nullification to the legal system no longer appears to be a matter of dispute.

256. Duncan v. Louisiana, 391 U.S. 145, 186-89 (1969) (Harlan, J., dissenting).

257. C. Curtis, It's Your Law 104 (1954).

258. G. Chesterton, Tremendous Trifles 86 (1920), quoted in M. Timothy, supra note 243, at 292 .

259. Juror errors are more often demonstrations of human fallibility than a weakness in the system. When an innocent defendant is convicted, the state has committed the original error in charging him, despite supposedly exhaustive investigations by police. The trained district attorney sustains it by prosecuting the case. The grand jury studies the charge and brings back a false indictment. The trained defense attorney presents an ineffectual defense. But only the trial jury is blamed if it brings in a false conviction.

G. Lehman, What You Need to Know for Jury Duty 83 (1968). 
structed that they may, on the basis of conscience, acquit a defendant when the strict application of the law would lead to an unjust or inequitable result.

The jury may not always be right, but neither is any other deliberative body. As the conscience of the community drawn from a representative cross section of that community, it is the best we have . . because it is us. ${ }^{260}$

260. To this day, when a man accused of serious crime is put in charge of the jury, it is in words which have come down through the centuries: 'To this charge he has pleaded not guilty and puts himself upon his country, which country you are.' All our past struggles are bound up in that one sentence. He entrusts his liberty to a jury of his fellowmen. So in the last resort do we all.

A. Denning, supra note 248 , at 59. 